
I. Farrera -S. P. Harrison - I. C. Prentice - G. Ramstein
J. Guiot • P. J. Bartlein · R. Bonnefille - M. Bush - W. Cramer
U. von Grafenstein · K. Holmgren · H. Hooghiemstra • G. Hope
D. Jolly · S.-E. Lauritzen · Y. Ono · S. Pinot • M. Stute · G. Yu

\section{Tropical climates at the Last Glacial Maximum: a new synthesis of terrestrial palaeoclimate data. l. Vegetation, lake-levels and geochemistry}

\begin{abstract}
Palaeodata in synthesis form are needed as benchmarks for the Palaeoclimate Modelling Intercomparison Project (PMIP). Advances since the last synthesis of terrestrial palaeodata from the last glacial maximum (LGM) call for a new evaluation, especially of data from the tropics. Here pollen, plant-macrofossil, lake-level, noble gas (from groundwater) and $\delta^{18} \mathrm{O}$ (from speleothems) data are compiled for $18 \pm 2 \mathrm{ka}$ $\left({ }^{14} \mathrm{C}\right), 32{ }^{\circ} \mathrm{N}-33{ }^{\circ} \mathrm{S}$. The reliability of the data was evalu-
\end{abstract}

\section{Farrera}

Laboratoire Paléoenvironnements et Palynologie, USTL,

Place Eugene Bataillon, F-34095 Montpellier cédex 5, France

S. P. Harrison ${ }^{1}(\varangle) \cdot$ I. C. Prentice ${ }^{2} \cdot$ D. Jolly ${ }^{1,2}$

Max Planck Institute for Biogeochemistry, PO Box 1001 64, D-07701 Jena, Germany

Also at:

${ }^{1}$ Dynamic Palaeoclimatology, Lund University, Box 117, S-221 Lund, Sweden

${ }^{2}$ School of Ecology, Lund University, Ecology Building, Sölvegatan 37, S-223 62 Lund, Sweden

G. Ramstein · U. von Grafenstein ${ }^{3} \cdot$ S. Pinot

Laboratoire des Sciences du Climat et de l'Environnement,

CEA Saclay, Bâtiment 709, Orme des Merisiers,

F-91191 Gif-sur-Yvette cédex, France

Also at:

${ }^{3}$ Geologie TU München, Lichtenbergstraße 4,

D-85747 Garching, Germany

J. Guiot

IMEP CNRS, Case 451, Faculté de St Jérôme,

F-13397 Marseille cédex 20, France

P. J. Bartlein

Department of Geography, University of Oregon,

Eugene, OR 97403, USA

R. Bonnefille

Palynology Laboratory, French Institute of Pondichery,

11 St. Louis Street., P.B. 33, Pondicherry 605 001, India

M. Bush

Department of Biological Sciences,

Florida Institute of Technology, 150 West University Boulevard,

Melbourne, FL 32901, USA ated using explicit criteria and some types of data were re-analysed using consistent methods in order to derive a set of mutually consistent palaeoclimate estimates of mean temperature of the coldest month (MTCO), mean annual temperature (MAT), plant available moisture (PAM) and runoff (P-E). Cold-month temperature (MAT) anomalies from plant data range from -1 to $-2 \mathrm{~K}$ near sea level in Indonesia and the S Pacific, through -6 to $-8 \mathrm{~K}$ at many high-elevation sites

W. Cramer

Potsdam Institute for Climate Impact Research (PIK),

Telegrafenberg, P.O. Box 6012 03, D-14412 Potsdam, Germany

K. Holmgren

Department of Physical Geography, Stockholm University, S-106 91 Stockholm, Sweden

H. Hooghiemstra

Department of Palynology and Paleo/Actuo-ecology,

University of Amsterdam, Kruislaan 318,

NL-1098 SM Amsterdam, The Netherlands

G. Hope

Research School of Pacific Studies,

Australian National University, Canberra 0200,

ACT, Australia

S.-E. Lauritzen

Department of Geology, University of Bergen,

Allégaten 41, N-5007 Bergen, Norway

Y. Ono

Laboratory of Geoecology, Graduate School

of Environmental Earth Science,

Hokkaido University, Sapporo 060, Japan

M. Stute

Lamont-Doherty Earth Observatory, Route 9W,

Palisades, NY 10964, USA

G. $\mathrm{Yu}^{1}$

Nanjing Institute of Geography and Limnology,

Chinese Academy of Science, Nanjing 210093, China

Also at:

${ }^{1}$ Dynamic Palaeoclimatology, Lund University,

Box 117, S-221 Lund, Sweden 
to -8 to $-15 \mathrm{~K}$ in $\mathrm{S}$ China and the SE USA. MAT anomalies from groundwater or speleothems seem more uniform $(-4$ to $-6 \mathrm{~K})$, but the data are as yet sparse; a clear divergence between MAT and coldmonth estimates from the same region is seen only in the SE USA, where cold-air advection is expected to have enhanced cooling in winter. Regression of all cold-month anomalies against site elevation yielded an estimated average cooling of -2.5 to $-3 \mathrm{~K}$ at modern sea level, increasing to $\approx-6 \mathrm{~K}$ by $3000 \mathrm{~m}$. However, Neotropical sites showed larger than the average sea-level cooling $(-5$ to $-6 \mathrm{~K})$ and a non-significant elevation effect, whereas $\mathrm{W}$ and $\mathrm{S}$ Pacific sites showed much less sea-level cooling $(-1 \mathrm{~K})$ and a stronger elevation effect. These findings support the inference that tropical sea-surface temperatures (SSTs) were lower than the CLIMAP estimates, but they limit the plausible average tropical sea-surface cooling, and they support the existence of CLIMAP-like geographic patterns in SST anomalies. Trends of PAM and lake levels indicate wet LGM conditions in the W USA, and at the highest elevations, with generally dry conditions elsewhere. These results suggest a colder-than-present ocean surface producing a weaker hydrological cycle, more arid continents, and arguably steeper-than-present terrestrial lapse rates. Such linkages are supported by recent observations on freezing-level height and tropical SSTs; moreover, simulations of "greenhouse" and LGM climates point to several possible feedback processes by which low-level temperature anomalies might be amplified aloft.

\section{Introduction}

The climate of the last glacial maximum (LGM) continues to present challenging problems for palaeoclimatologists and climate modellers, now nearly $20 \mathrm{y}$ after the publication of Peterson et al.'s (1979) pioneering synthesis of terrestrial palaeodata and the CLIMAP $(1976,1981)$ reconstruction of conditions at the ocean surface. In some ways, our ignorance of the processes determining the nature of the glacial climate regime appears to have grown since then. The existence of ice-core records and the resulting discovery of major changes in the atmospheric concentrations of the greenhouse gases $\mathrm{CO}_{2}, \mathrm{CH}_{4}$ and $\mathrm{N}_{2} \mathrm{O}$ between the LGM and Holocene has presented new, unsolved problems about the regulation of natural changes in global biogeochemical cycles, their linkages to one another and their coupling with the physical climate system (Lorius and Oeschger 1994). The discovery of rapid climate changes during the last glacial period challenges our ability to predict the coupled physical dynamics of atmosphere, ocean and ice (Johnsen et al. 1992; Bond et al. 1993; Broecker 1997). The need to understand the processes which bring about major state changes in the Earth's climate is made clear by atmosphere-ocean model simulations showing that there are complex transient effects in the response of climate to anthropogenic changes in greenhouse gas budgets (Rahmstorf 1994; Stocker and Schmitter 1997), and suggest a potential for further feedbacks on atmospheric carbon dioxide concentration $\left[\mathrm{CO}_{2}\right]$ (Sarmiento and le Queré 1996; Sarmiento et al. 1998). A focus on the tropics, in particular, is justified by the current debate about the effectiveness, or otherwise, of homeostasis in tropical temperatures when forced by changes in $\left[\mathrm{CO}_{2}\right]$ (Kattenberg et al. 1996). If we are able to reconstruct and successfully model the climate response of the tropics at the LGM, we will have reason to be more confident in our ability to estimate the global climate sensitivity to changes that may be brought about by human actions.

Several scientific developments since the Peterson et al. (1979) synthesis have greatly increased the amount of information available on the state of different aspects of the Earth system at the LGM. They include:

\subsection{LGM boundary conditions}

These can now be specified with greater confidence and precision than was possible when the first simulations of LGM land climates were performed (Williams et al. 1974; Gates 1976; Manabe and Hahn 1977; Manabe and Broccoli 1985a, b; Broccoli and Manabe 1987; Kutzbach and Guetter 1986). We now have a globally consistent reconstruction of ice distribution and relative sea-level changes from the LGM to present (Peltier 1994); measurements of LGM atmospheric concentrations of the major greenhouse gases (Barnola et al. 1987; Chappellaz et al. 1990; Leuenberger and Sigenthaler 1992); and a better specification of LGM insolation forcing following the discovery that the ${ }^{14} \mathrm{C}$ age of $18 \mathrm{ka}$ for the LGM represents $\approx 21 \mathrm{ka}$ in astronomical years (Bard et al. 1990; Kutzbach et al. 1993).

\subsection{Palaeoclimate modelling}

This has advanced considerably, due to the availability of faster computers and the progressive refinement of atmospheric and ocean models. Palaeoclimate simulations with atmospheric general circulation models are now commonly performed for $\geq 10$ annual cycles, and often include interactive oceanic components. The achievable spatial resolution in global models has improved to $2-3^{\circ}$, and representations of land-atmosphere interactions have become more realistic (Houghton et al. 1996). Simulations including coupling to dynamical ocean models (e.g. Kutzbach and Liu 1997; Hewitt and Mitchell 1998) and biosphere models (e.g. Foley et al. 1998) can now be undertaken. In 
addition, simplified, lower-resolution but fast models are being developed that show promise in elucidating the long-term interactions of different components of the climate system (Ganopolski et al. 1998). The generality of model results can be assessed thanks to the Palaeoclimate Modeling Intercomparison Project (PMIP) (Joussaume and Taylor 1995; Joussaume et al 1998; Pinot et al. this volume), which has specified a small number of standard model experiments for $6 \mathrm{ka}$ and $21 \mathrm{ka}$ that are being carried out by about 20 modelling groups.

\subsection{Acquisition of terrestrial palaeodata from the LGM}

This has continued, and in particular there have been major efforts to obtain records from sediment cores in previously data-sparse regions in the tropics. Dating accuracy has also improved thanks to the increasing use of AMS for ${ }^{14} \mathrm{C}$-dating small samples of material of identifiably terrestrial origin (e.g. plant macrofossils), thus avoiding the problems of dating sediments mostly devoid of carbon.

\subsection{Data syntheses}

These have been carried out on a more comprehensive and rigorous basis than before, starting with the Global Lake Level Data Base (Street-Perrott et al. 1989) and the regional pollen and lake-level data compilations carried out within the COHMAP project (Wright et al. 1993) and continuing through the IGBP-sponsored BIOME 6000 project (Prentice and Webb 1998), which includes the compilation of pollen records for the LGM and their translation into palaeobiomes using a standard methodology (Prentice et al. 1996; Prentice, Jolly and BIOME 6000 participants, unpublished data).

\subsection{Understanding and interpretation of the "classical" data sources}

This has improved greatly. Different types of data often respond to different seasonal aspects of climate, and such differences may account for apparent discrepancies between proxies (e.g. the coexistence of high lake stands with steppe vegetation in the Mediterranean region at LGM: Prentice et al. 1992a). Calibration methods using multiple data sets have been developed (Guiot et al. 1993). Possible effects of $\mathrm{CO}_{2}$ on treeline elevations (Street-Perrott 1994; Crowley and Baum 1997; Street-Perrott et al. 1997) have been recognized and included in ecosystem models (Jolly and Haxeltine 1997). Interpretation of changes in equilibrium-line altitude (ELA) of glaciers is understood to require consideration of precipitation changes as well as temperature changes (Zielinski and McCoy 1987; Hostetler and Clark 1997), and observational and modelling studies of recent glacier variations have suggested the existence of feedbacks that may amplify the response of ELA to temperature changes at sea level (Oerlemans 1986; Crowley and Kim 1996; Diaz and Graham 1996; Crowley and Baum 1997; Martin et al. 1997).

\subsection{New data sources}

These have been developed, including the "noble gas thermometer" in groundwater (Stute et al. 1992; Stute and Schlosser 1993) and $\delta^{18} \mathrm{O}$ in speleothems (Lauritzen 1993, 1996) as records of mean annual (subsurface) temperatures on land.

\subsection{Our understanding of the temporal context of the LGM}

This has changed drastically, due to the recognition of large synchronous climate fluctuations during the glacial stages in high-resolution climate records from Greenland ice (Johnsen et al. 1992; Dansgaard et al. 1993), marine foraminiferal records (Bond et al. 1993), terrestrial pollen records (Grimm et al. 1993; Watts et al. 1996) and loess (Porter and An 1995; Guo et al. 1996; Chen et al. 1997). This context makes it important to consider the relative response times of different types of data, and to avoid the mistake of correlating LGM with short-lived cold episodes, such as the last Heinrich event (H1) in the North Atlantic. Thus, the selection of data to correspond to the LGM should be based on independent dating, and not simply on locating the most extreme conditions during the much longer period correlative with isotope stage 2 .

\subsection{Our purpose}

Against this background, we find it timely to present a new synthesis of the available palaeoclimatic data from terrestrial records at the LGM. We focus on the region between $32^{\circ} \mathrm{N}$ to $33^{\circ} \mathrm{S}$, because of the continuing interest in the problem of reconciling terrestrial and marine records from the tropics (Webster and Streten 1978; Rind and Peteet 1985; Anderson and Webb, 1994; Guilderson et al. 1994; Thompson et al. 1995; Broecker 1997) and because of the key importance of the tropical temperature response in discussions about future climates (Houghton et al. 1996). The choice of latitudinal limits beyond the tropics (sensu stricto) enabled us to include important data points from the subtropics.

We define the LGM by a ${ }^{14} \mathrm{C}$-age bracket of $18 \pm 2 \mathrm{ka}$. Although this period was clearly not climatically homogeneous, the independent dating control on most records is insufficient to allow greater precision while the $\pm 2 \mathrm{ka}$ tolerance range is narrow enough 
to exclude the largest anomalies, namely the Heinrich events that occurred before $\left(\mathrm{H} 2: \approx 22-21 \mathrm{ka}{ }^{14} \mathrm{C}\right)$ and after $\left(\mathrm{H} 1: \approx 15-14 \mathrm{ka}{ }^{14} \mathrm{C}\right)$ the LGM (Bond et al. 1993). This chronological criterion is applied strictly. Thus, we do not consider data from other times during isotope stage 2 as representing the LGM. This is an important difference between our approach, which is oriented towards comparison with model results (Pinot et al. this volume) for a specific time period, and some discussions in the literature which have focused on the question of the maximum degree of cooling during the entire last glacial interval (e.g. Colinvaux et al. 1996). We insist on the distinction because the LGM as defined in terms of global ice volume does not necessarily coincide with the timing of maximum cooling (or even local glacier advance) in any particular region. If data were aggregated from a broader time interval, the result might be a composite of diachronous climates and might therefore correspond to no physically possible state of the global climate system.

Our principal aim has been to assemble the extant information on tropical terrestrial palaeoclimates at the LGM from the approximately 200 sites that fall in the geographical and temporal ranges specified, and to extract where possible quantitative estimates of the difference between LGM and present climate. Geochemical or statistical methods have been used to reconstruct climatic differences at a limited number of sites; these reconstructions were accepted without modification provided they met certain standards. More often indirect estimates have been made, e.g. based on converting elevation shifts of vegetation zones to changes in temperature. We re-evaluated these indirect estimates, based on the originally published data, using a standard methodology including an objective method to estimate lapse rates. Estimates of aspects of the water balance (plant-available moisture and precipitation minus evapotranspiration) were also compiled, but on a qualitative basis.

\section{Potential sources of information on tropical palaeoclimate}

Many data sources could potentially be used to reconstruct tropical palaeoclimates. No one source has all the characteristics to make it ideal: wide spatial distribution, high temporal resolution, good dating control, direct and well-understood climatic controls, and the potential to yield quantitative climate reconstructions. Furthermore, since individual types of data respond to different seasonal aspects of the climate, multiple types need to be used when reconstructing past climates. The use of multiple types of data also makes it possible to check whether reconstructions based on individual types are physically consistent. The data sources used here are pollen and plant macrofossil records; geochemical and isotopic records from fossil water or carbonates; and lake-level reconstructions based on geomorphic and stratigraphic records. A new synthesis of glacial ELA reconstructions from geomorphic records in tropical mountain regions in underway, and will be reported in a subsequent study (Part II). In the following section we describe the characteristics of each data type in turn, and its relationship to climate.

\subsection{Pollen and plant macrofossil data}

Pollen grains are quantitatively preserved in mire and lake sediments that can be dated by ${ }^{14} \mathrm{C}$. Pollen data are the largest and most widespread source of information on Late Quaternary palaeoenvironments. Despite differences in the production and dispersal of pollen from different plant taxa, pollen assemblages from sediments can be interpreted as a quantitative record of the surrounding vegetation (Prentice 1988). Regionally dominant taxa are normally well represented and smaller counts of less abundant taxa provide additional information, allowing pollen assemblages to be assigned correctly to biomes (Prentice et al. 1996). Procedures to assign biomes, and to make palaeoclimate estimates, can be calibrated using the large sets of pollen data in modern (surface) samples that have been assembled for many regions (e.g. Guiot 1990; Cheddadi et al. 1996; Jolly et al. 1998b; Yu et al. 1998)

Most pollen grains are identifiable to genus or family. Plant macrofossils can often be identified to species. Macrofossils are preserved in some sediments and can provide additional information, for example by distinguishing climatically indicative species within widely distributed genera (Jackson et al. 1997). Macrofossils are abundant in middens made by Neotoma (packrats) or Hyrax in arid regions. Such middens are ${ }^{14} \mathrm{C}$-datable and provide a rich source of information on Late Quaternary palaeoenvironments (Van Devender et al. 1987).

Plant taxon and biome distributions are highly sensitive to several aspects of the atmospheric environment. These geographic distributions can be characterized today in a climate space which globally has at least three dimensions, e.g. the mean temperature of the coldest month (MTCO), total growing-season warmth (indexed by growing degree days above a threshold temperature for growth), and plant-available moisture (PAM) (Woodward 1987; Prentice et al. 1992b; Sykes et al. 1996). (PAM represents the availability of soil moisture to satisfy the plants' demand for evapotranspiration; if PAM is reduced, plant carbon gain is also reduced.) Knowing the biome, or knowing the assemblage of plants and their bioclimatic ranges, one can locate a given palaeoenvironment in this space. Changes in pollen assemblages therefore often give information about changes in more than one climate variable (for example, the effects of changes in cold-month temperatures and PAM have different and independent effects on vegetation). Various techniques are used to make climatic inferences, including qualitative comparisons of plants identified with their modern distributions; quantitative estimates of minimum and maximum changes required to produce a given biome shift; and quantitative palaeoclimate estimates based on statistical calibration of modern pollen samples (transfer-function, modern-analog and response surface techniques: Guiot 1991; Bartlein and Whitlock, 1993).

In tropical mountain regions, comparisons of LGM-age pollen samples with vegetation or modern pollen samples from different elevations have often been used to estimate shifts in the apparent elevation of specific forest belts or treeline. The reconstructed shifts in apparent elevation are then multiplied by a lapse rate to yield temperature change estimates. However, since photosynthesis and stomatal conductance are sensitive to atmospheric $\left[\mathrm{CO}_{2}\right]$, variations in $\left[\mathrm{CO}_{2}\right]$ can in principle modify the response of plants to climate and therefore constrain the locations of plant distributions in climate space. Biome-level responses can only be inferred by ecosystem modelling based on experimental results at the plant and ecosystem levels because $\left[\mathrm{CO}_{2}\right]$ is essentially constant spatially today (Walker and Steffen 1997). Nevertheless, the LGM distributions of plant taxa and biomes in relation to climate may have been modified by low $\left[\mathrm{CO}_{2}\right]$ (Davis, 1991). Tropical mountain treeline, in particular, is thought to be potentially sensitive to low $\left[\mathrm{CO}_{2}\right]$. The trees near treeline exist today under conditions of extremely low primary productivity, due to a combination of year-round low temperatures and a low internal partial pressure of $\left[\mathrm{CO}_{2}\right]$ (StreetPerrott 1994; Street-Perrott et al. 1997). If $\left[\mathrm{CO}_{2}\right]$ were further lowered then primary productivity could become too low to sustain tree growth. One model result indicates that LGM treelines in the 
tropics might have been lowered by hundreds of metres due to physiological effects of $190 \mathrm{ppmv}\left[\mathrm{CO}_{2}\right]$, i.e. a lowering of the same order of magnitude as that observed (Jolly and Haxeltine 1997).

Changes in the upper elevational limits of montane forest belts, however, are probably unresponsive to $\left[\mathrm{CO}_{2}\right]$. The upper elevational limits of lowland and lower-montane rainforest trees are determined by the fact that these taxa, unlike taxa from higher elevations, have no protection mechanisms against chilling or frost (Woodward 1987). We therefore assume that these limits are controlled by MTCO. In the tropics sensu stricto and especially in the wet tropics, MTCO and mean annual temperature (MAT) must be closely correlated because of the relatively low seasonal range of temperatures. In the subtropics these two variables can diverge, e.g. any mechanism that would produce colder winters while not affecting the other seasons would reduce MTCO considerably more than MAT.

Low $\left[\mathrm{CO}_{2}\right]$ at the LGM might also have led to "physiological drought" since stomatal conductance is generally greater at low $\left[\mathrm{CO}_{2}\right]$, causing greater transpiration per unit leaf area, and is likely to have favoured plants with the $\mathrm{C}_{4}$ pathway of photosynthesis (e.g. tropical grasses), which concentrate $\mathrm{CO}_{2}$ around the chloroplasts, over the $\mathrm{C}_{3}$ pathway used by most temperate plants and all trees. These effects would not be confined to high elevations and might have contributed to a general reduction in PAM, as defined here, and an expansion of tropical grasslands at the expense of forests.

\subsection{Noble gases in groundwater}

The solubility of the noble gases $(\mathrm{Ne}, \mathrm{Ar}, \mathrm{Kr}, \mathrm{Xe})$ in water is temperature dependent. Both solubility and its sensitivity to temperature increase with atomic mass (Mazor 1972). As water percolates from the land surface through the unsaturated soil zone during groundwater recharge, the noble gas content of the water equilibrates with that of the air in the soil pore space. Exchange ceases once the water reaches the underlying aquifer. Thus, in principle, the noble gas spectrum of groundwater reflects the temperature in the unsaturated soil zone at the time and place of recharge (Herzberg and Mazer 1979; Stute and Schlosser 1993). In reality, measured noble gas concentrations are often higher than might be expected given perfect equilibration. This additional component, termed "excess air" is most likely caused by fluctuations of the water table, trapping small air bubbles that are then dissolved under increased hydrostatic pressure (Heaton and Vogel 1981). Some of this excess air may subsequently be lost by secondary gas exchange across the water table. The excess air contribution is unknown a priori. However, because excess air differentially affects the apparent temperature reconstructed from the different gases (the greatest effect is on the lightest, least soluble $\mathrm{Ne}$, the smallest effect on Xe), true noblegas temperature can be estimated by subtracting an excess air contribution that yields similar temperature estimates (within measurement errors) for all four gases (Stute and Schlosser 1993; Stute et al. 1995).

In confined aquifers, isolated from the atmosphere, the groundwater flows downstream to the discharge area carrying a temperature signal imprinted in the recharge area. Typical groundwater flow velocities in confined aquifers are of the order of $1 \mathrm{~m} \mathrm{y}^{-1}$. As a result, a $50 \mathrm{~km}$ long aquifer many potentially provide a $50000 \mathrm{y}$ long record of temperatures in the recharge zone. However, small-scale mixing processes (dispersion) which occur during groundwater flow mean that this record is temporally smoothed. Typical dispersion coefficients are of the order of 10 to $100 \mathrm{y}$. Model calculations suggest that, for typical flow velocities and dispersion coefficients, the smoothing effect at the LGM is of the order of 2000 to 5000 y (Stute and Schlosser 1993).

Radiocarbon provides the only well-established method of dating groundwater. The geochemical evolution of the groundwater must be taken into account in order to derive reliable ${ }^{14} \mathrm{C}$ estimates
(Fontes and Garnier 1979). Comparison of correction models (e.g. Phillips et al. 1989) suggests that errors on the order of $\pm 2000 \mathrm{y}$ should be assigned to ${ }^{14} \mathrm{C}$ ages on groundwater.

Thus, the "noble gas thermometer" can be used to provide quantitative estimates of changes in mean annual ground temperature in the recharge zone. Ground temperature can be equated with mean annual temperature (MAT), except in regions where seasonal snow cover drastically changes the thermal insulating properties of the surface, which is not a concern for any of the sites used here. Groundwater measurements cannot provide high resolution records, partly because of the smoothing of the climate signal caused by dispersion processes, and partly because of the dating errors, but the estimates are presumably reliable for the glacial-interglacial time scale. A caveat is that because of the inherent averaging, the record may also incorporate information from extreme events within the effective averaging period. Another possible uncertainty concerns the location of the recharge zone relative to the sampling site. However, any errors introduced by not knowing the exact location of the recharge zone are probably slight, for two reasons. First, the accuracy of noble-gas temperature estimates for the present day supports the reliability of estimates for the past. Second, any possible error due to incorrectly specifying the elevation of the recharge zone is strongly compensated for by the opposing effects of atmospheric pressure and temperature on the solubility of noble gases.

\section{$2.3 \delta^{18} \mathrm{O}$ in speleothems}

Speleothems (stalactites, stalagmites, dripstone) are secondary calcium carbonate deposits, precipitated in caves. Speleothem growth is favoured when there is adequate precipitation to produce seepage water and when the ground surface is vegetated so that this seepage water is carbonated, while growth is limited by extreme cold, extreme aridity and when the cave is flooded by water. The isotopic and mineralogical composition of speleothems is determined by the regional climatic and environmental conditions at the time of precipitation. Provided that the $\delta^{18} \mathrm{O}$ of the palaeoprecipitation can be measured, for example in old groundwater, the $\delta^{18} \mathrm{O}$ in the speleothem carbonate can be used to estimate the absolute cave temperature at the time of formation (Hendy 1971; Schwarcz 1986). Cave temperatures are generally stable, approximating to the mean annual ground temperature of the region. Speleothems can be precisely dated with the uranium-series method (Schwarcz 1986; Li et al. 1989).

The use of speleothems to reconstruct past climate changes is new and there are few sites from the tropics. Most of these speleothem records have been interpreted as providing estimates of relative changes in various climatic parameters, based for example on an assumed correlation of growth rates with climate (Shaw and Cooke 1986; Brook et al. 1997), or interpretation of isotope excursions either on the assumption that they reflect single climatic parameters (e.g. Fischer et al. 1996), or by deconvolution of the temperature/precipitation signals using information from other data (Holmgren et al. 1995; Bar-Matthews et al. 1997; Burney et al. 1997). Lack of independent information on the $\delta^{18} \mathrm{O}$ composition of fossil cave seepage waters has so far prevented the quantitative interpretation of tropical speleothem records except in the single case of Cango Cave in South Africa (Talma and Vogel 1992). We include this record in the present synthesis because it provides an independent check on the MAT reconstruction from South Africa based on the noble-gas thermometer.

\subsection{Lakes}

Water-level changes in lakes can occur on a variety of time scales, from intra-annual to geological. The concomitant changes in water depth affect many of the physical and biological parameters of the 
lake, allowing changes in water level to be inferred from the sedimentary or biostratigraphic records preserved in the deposits in or at the margins of lakes (Street-Perrott and Harrison 1985; Harrison and Digerfeldt 1993). Except under exceptional circumstances, when the seasonal changes in the biota or sediments are preserved in the form of annual laminations, lake deposits generally only provide records of the sustained, longer-term $\left(10^{2}-10^{4} \mathrm{y}\right)$ changes in water depth. Such records have been obtained from most regions of the world (e.g. see Street-Perrott et al. 1989; Fang 1991; Yu and Harrison 1995; Tarasov et al. 1996; Jolly et al. 1998a). Changes in water level can be caused by local factors, e.g. damming of the outlet, geomorphic changes causing re-routing of river inflows, changes in catchment land-use, and tectonism (Dearing and Foster 1986). In general, these factors affect only individual lakes. Regionally synchronous changes can be assumed to reflect changes in the hydrological balance, driven by changes in climate.

Overflowing lakes approach an equilibrium area, such that the sum of runoff from the catchment and the (positive) water balance over the lake surface is balanced by discharge (Szestay 1974; StreetPerrott and Harrison 1985; Mason et al. 1994). Discharge is a monotonic function of lake volume; the form of the function depends on the morphometry of the lake and its outlet (Henderson-Sellers 1984). A lake becomes closed (i.e. ceases to overflow) when the water balance over the lake surface is negative and can therefore alone balance the runoff from the catchment. Generally, lake area and depth vary monotonically with $P-E$, the (always positive) balance of precipitation and evaporation over the catchment (Cheddadi et al. 1996). Reconstructed changes in lake status (area, depth, or level) can therefore be used to infer the sign of changes in mean annual $P-E$.

Plant-available moisture (PAM) and $P-E$ are estimated independently, and are not automatically related. In simple scenarios where annual precipitation changes while its seasonality and other factors do not change, both measures must change in the same direction. But there are other possibilities, especially in seasonal climates. For example, increased precipitation in the dry season can be balanced by increased evapotranspiration (promoted by vegetation growth); this would register as increased PAM and no change in $P-E$. Increased precipitation and decreased evapotranspiration in the already-wet season could conversely produce increased $P-E$ without increasing PAM (Prentice et al. 1992a).

Although lakes usually provide only qualitative records of climate changes, several characteristics make them useful for reconstructing tropical climate changes at the LGM. The climatic controls on the lake water balance are well known (Street-Perrott and Harrison 1985; Cheddadi et al. 1996). Lake records are widely distributed and records of former lakes are common in arid areas. Lake bottom and lake marginal sediments represent a quasi-continuous record of long-term changes, and generally provide material suitable for ${ }^{14} \mathrm{C}$ dating.

\section{Methods}

For each proxy data source, the published literature was surveyed and a listing was made of all of the sites between $32^{\circ} \mathrm{N}$ and $33^{\circ} \mathrm{S}$ providing either qualitative or quantitative palaeoclimatic information for the LGM. The LGM was defined by a ${ }^{14} \mathrm{C}$-age bracket of $18 \pm 2 \mathrm{ka}$. Site-specific information was obtained either from the published articles or from public-access data bases. Although the chronology of every site is based on radiometric methods, the quality of the dating varies between different parts of the record at a single site, between different sites and between different types of records. In addition to giving the total number of dates on which the chronology is based (where this is an appropriate measure of reliability), we have also provided an assessment of the quality of the LGM dating control (DC) at each site using the COHMAP scheme (Webb 1985) implemented according to Yu and Harrison (1995). The palaeoclimatic information for each site as given in the original articles is listed systematically. For completeness, Tables 1-4 list all of the original estimates available at each site, including re-interpretations of the proxy data, re-analyses using improved techniques, and multiple studies.

Not all of the palaeoclimatic reconstructions in the published literature are reliable by today's standards. In some cases the underlying assumptions and methods cannot be identified. Some other reconstructions have been based on incorrect conceptual models, techniques now superseded, or wrong assumptions. We have therefore closely evaluated individual records, using explicit criteria to assess their reliability. Only sites which meet these explicit criteria are included in the mapped analyses presented later (Fig. 1). In some cases (e.g. the interpretation of changes in vegetation zone elevations) we have re-analyzed the original data in order to derive a set of mutually consistent palaeoclimatic estimates. The explicit evaluation criteria used for each data source are described below, as are the methods employed in any re-analyses. All of the estimates that we consider reliable, and use in subsequent analyses, are clearly identified in Tables 1-4. Thus, the data as presented in Tables 1-4 make clear wherever we are using an interpretation that deviates from the originally published one, and the underlying logic of our interpretation.

\subsection{Estimation of changes in MTCO from pollen and plant macrofossil records}

Most of the estimates of tropical temperature changes given in the literature (Table 1) have been obtained by estimating an elevation shift (of one or more climatically sensitive plant species, or of a vegetation zone) and multiplying by a lapse rate, corresponding to an estimate of the rate of decline of temperature with elevation. In some cases the elevation shift has been estimated with some precision, in which case we use a single value as a point estimate; in other cases we know only a minimum, a maximum, or a range. Uncertainty is also introduced by the choice of lapse rate. As the relevant temperature here is the temperature near the ground, the lapse rate that applies is the "terrestrial" or "slope" lapse rate. Although values similar to the free-air moist adiabatic lapse rate $\left(\approx 5 \mathrm{~K} \mathrm{~km}^{-1}\right.$ at temperatures typical of the lowland tropics) are typically used for this purpose, terrestrial lapse rates can be significantly greater than or less than the moist adiabatic lapse rate. Terrestrial lapse rates can also show large seasonal variations (P.J. Bartlein, J. Guiot, unpublished results). Seasonally and locationally dependent terrestrial lapse rates can be estimated statistically by smooth three-dimensional interpolation of weather station data on monthly mean temperatures.

In the palaeoecological literature the lapse rate used is not always specified, and it is seldom possible to determine whether the value used was an appropriate local terrestrial lapse rate or a generic figure. Some differences between successive estimates (based on the same data), and some differences between author's estimates obtained from nearby sites, may reflect varying choices of values for the lapse rate. We have therefore re-estimated changes in MTCO wherever these were based on inferred change in the elevations of specific vegetation boundaries. In each case we applied a local (modern) terrestrial lapse rate, evaluated at the latitude, longitude and elevation of the site, using a data set of long-term monthly mean temperatures from 9176 meteorological stations worldwide (the data set is an updated version of the one used to generate the IIASA data set of Leemans and Cramer 1991). Of these stations, 3346 are located between $32^{\circ} \mathrm{N}$ and $33^{\circ} \mathrm{S}$. The lapse rate is calculated as the derivative with respect to elevation of a non-linear function fitted to the monthly data in the space of latitude, longitude and elevation using an artificial neural network (Peyron et al. 1988). We distinguish between those sites where the estimated change in MTCO was calculated on the basis of a change in treeline and those for which MTCO was calculated on the basis of changes in forest zones, in order to be able to allow for a possible contribution of $\left[\mathrm{CO}_{2}\right]$ to treeline changes. 


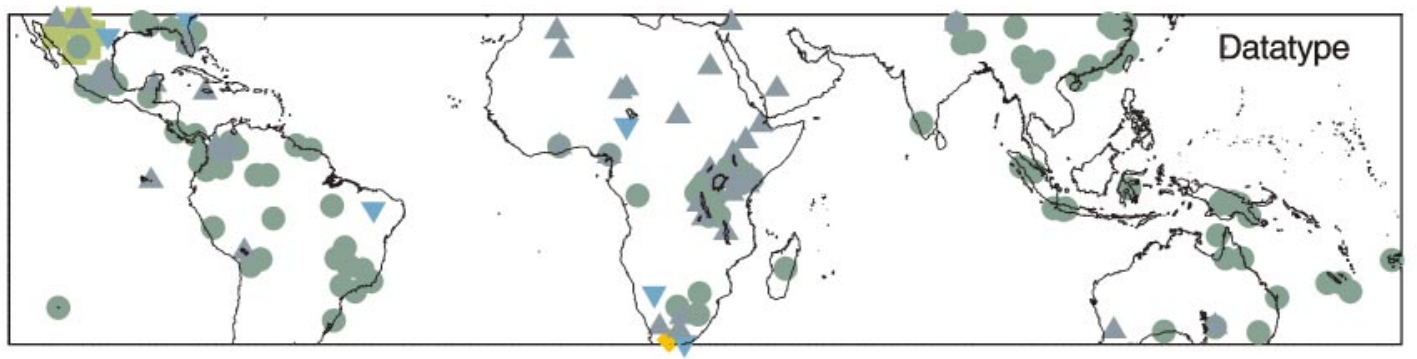

Pollen

$\nabla$ Noble Gas

Plant Macrofossils

Speleothem

- Lake Status

Fig. 1 Distribution of sites, according to data type. This map does not show those sites at which the estimates derived from the literature (listed in Tables 1-4 for completeness) do not match our criteria for reliability and which were therefore not used in subsequent

analyses. Site locations have been shifted by up to a few degrees in data dense areas; however, the location of a given site is the same on each map on which it appears
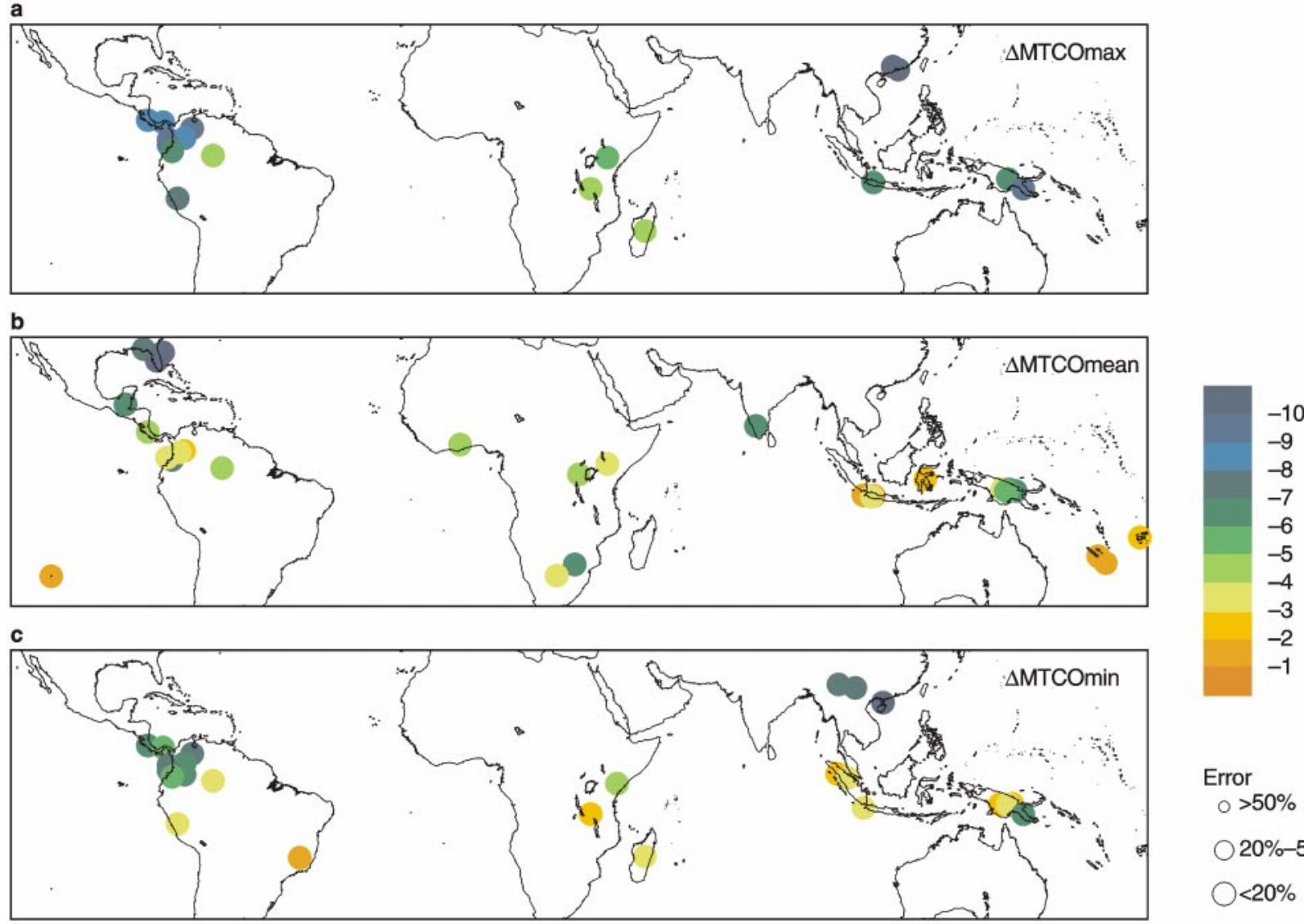

Error

O $>50 \%$

$20 \%-50 \%$

○ $<20 \%$

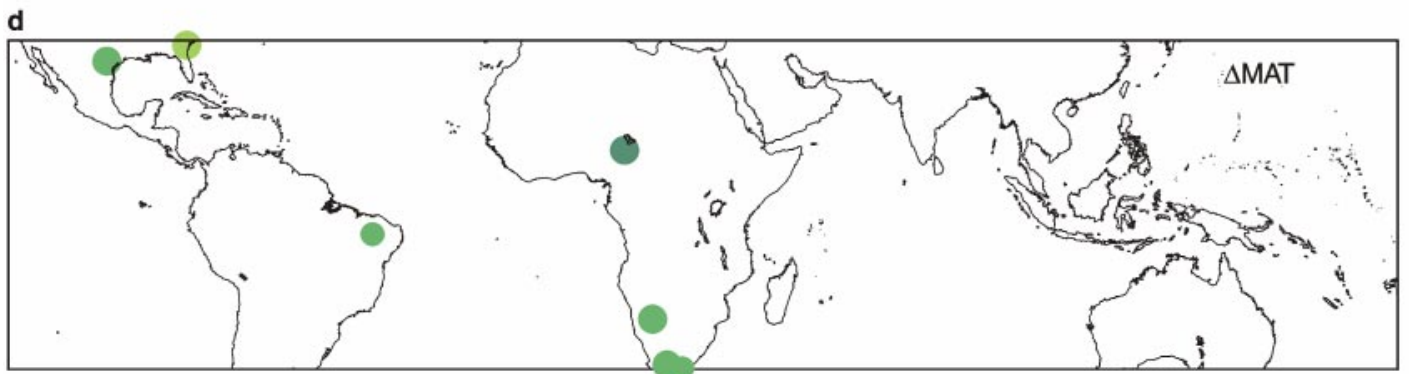

Fig. 2a-c Anomalies (LGM minus present) of cold-month temperatures (MTCO) based on pollen data. Maximum and/or minimum estimates based on lapse rate calculations are shown at all sites where the elevation shift is given in this form $\mathbf{d}$ Anomalies of mean annual temperature (MAT) based on noble gas and speleothem data 


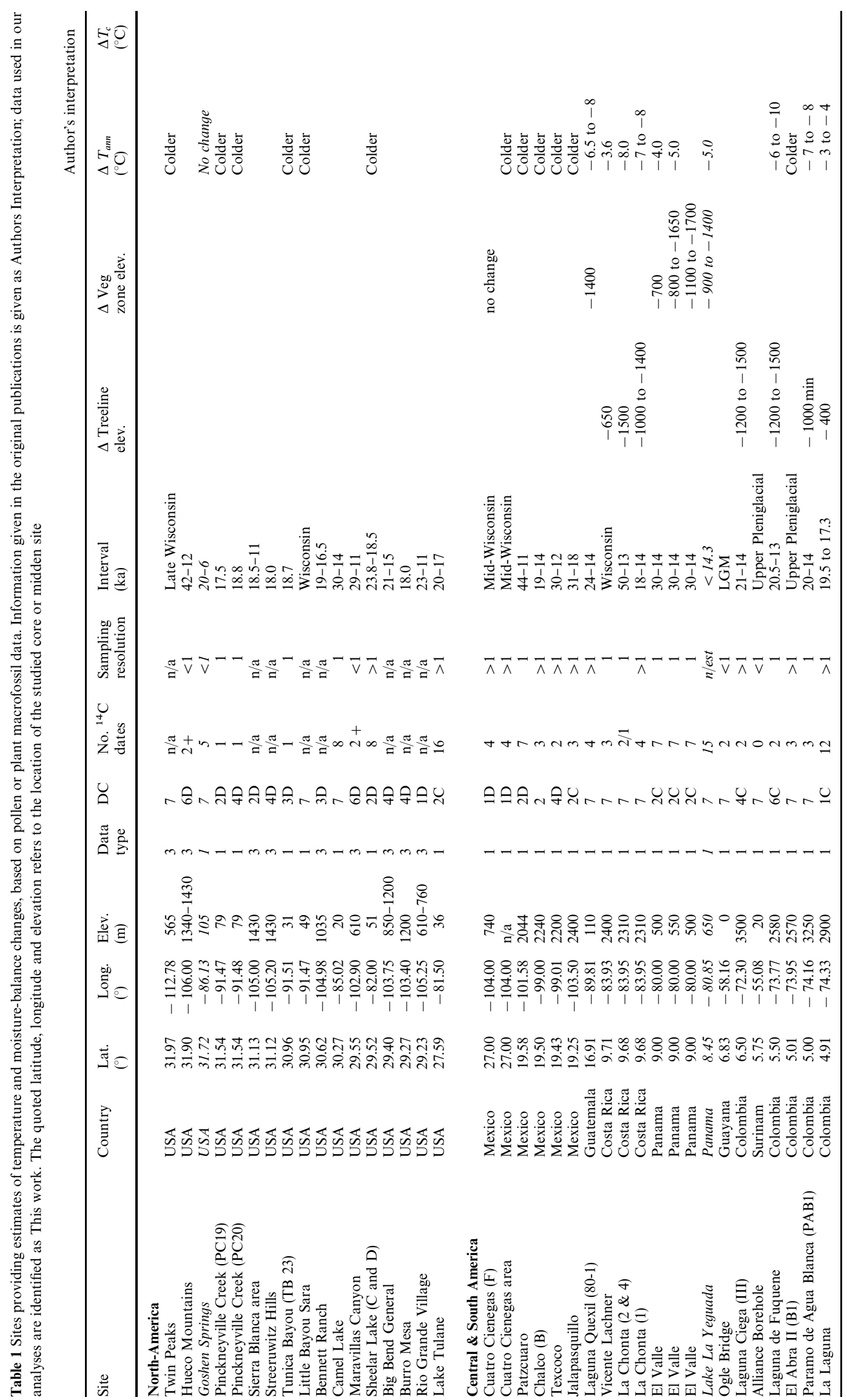




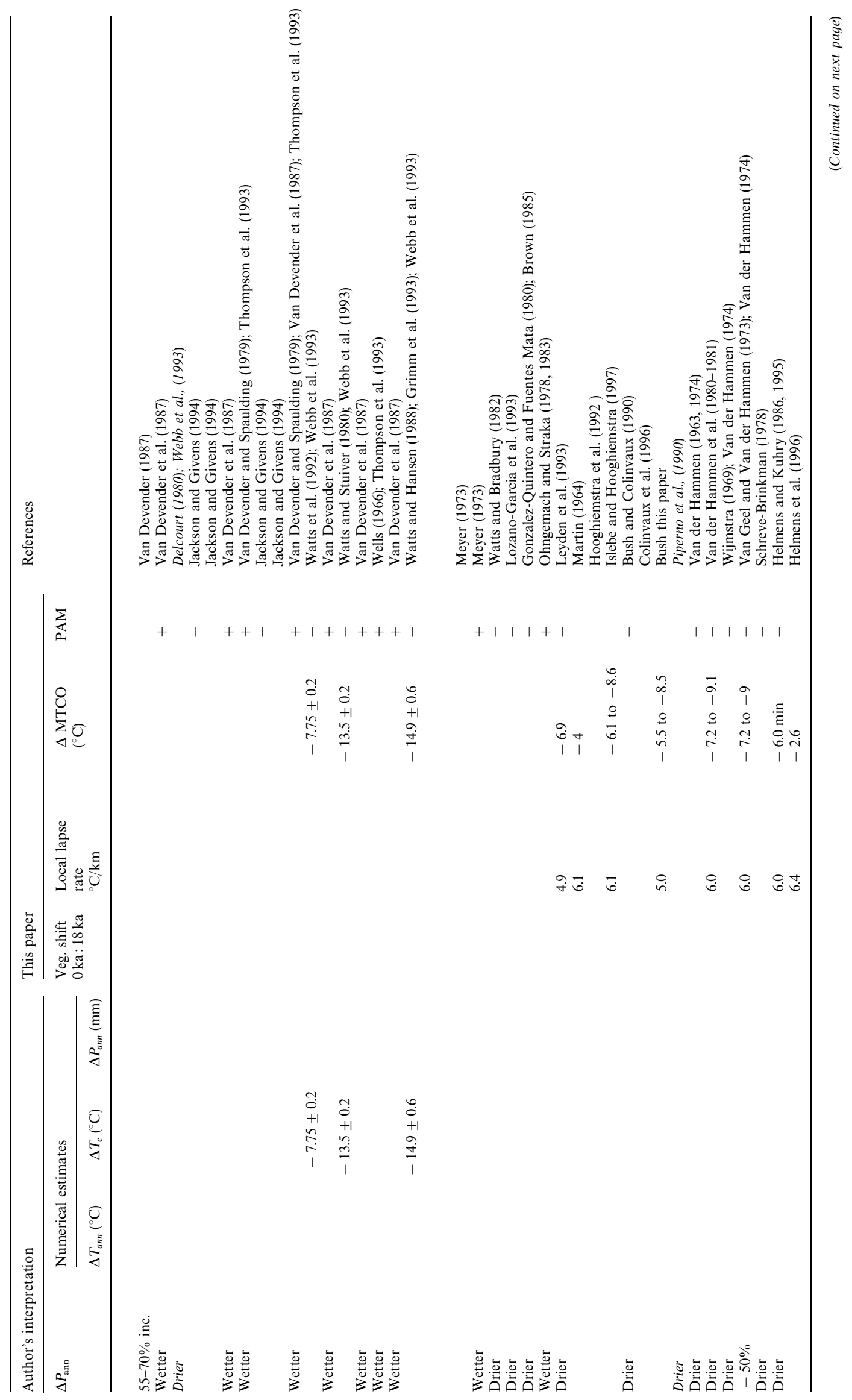




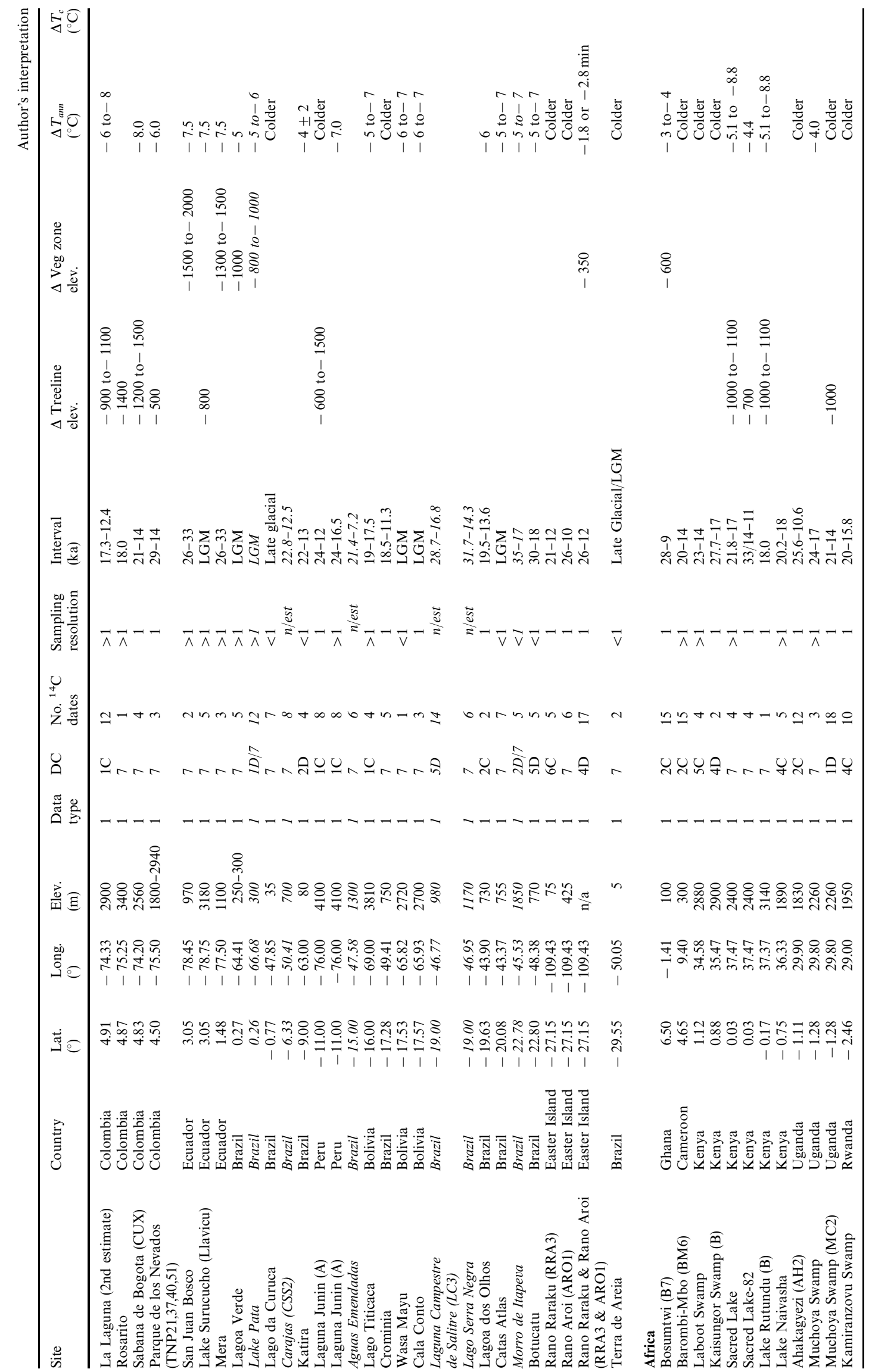




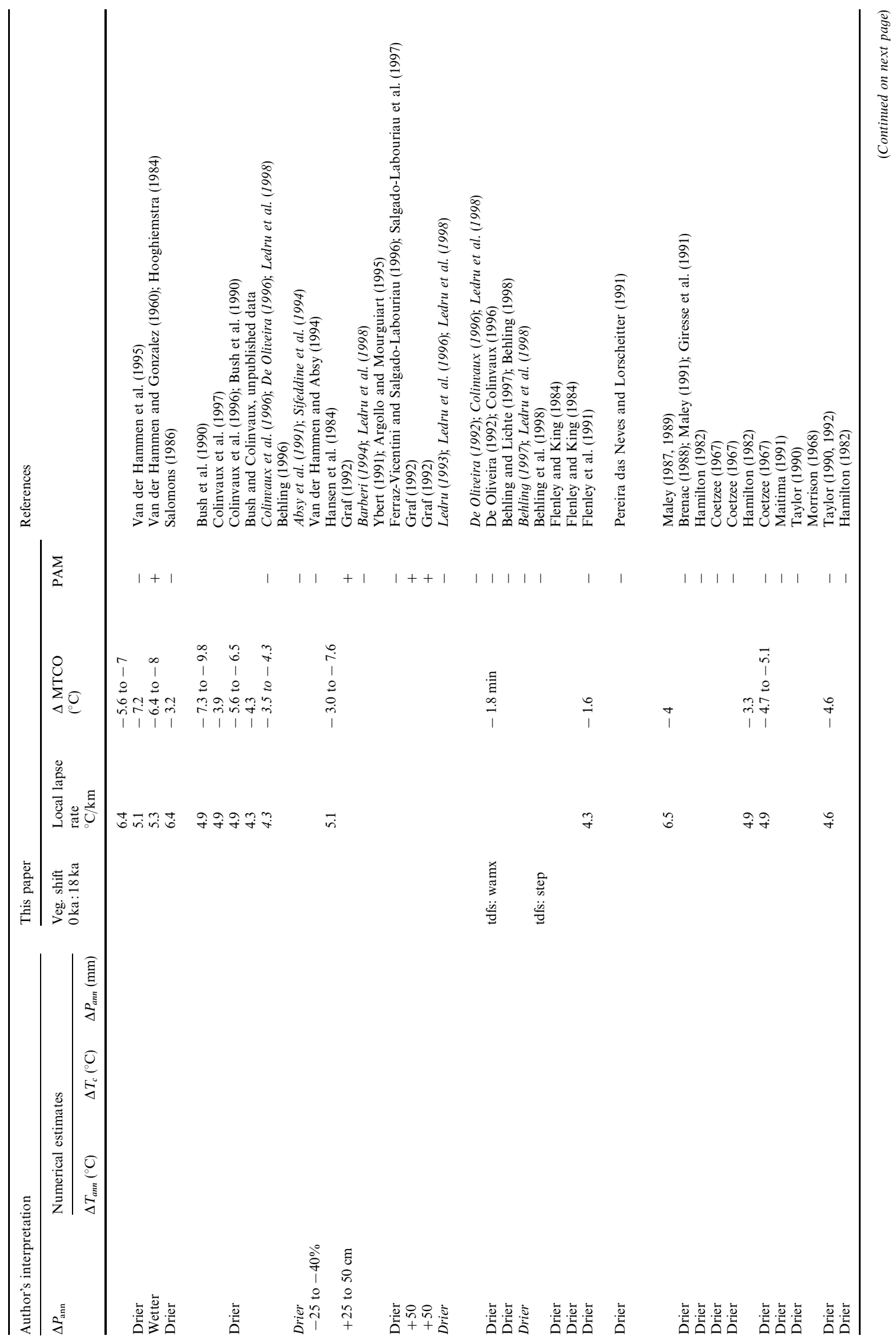




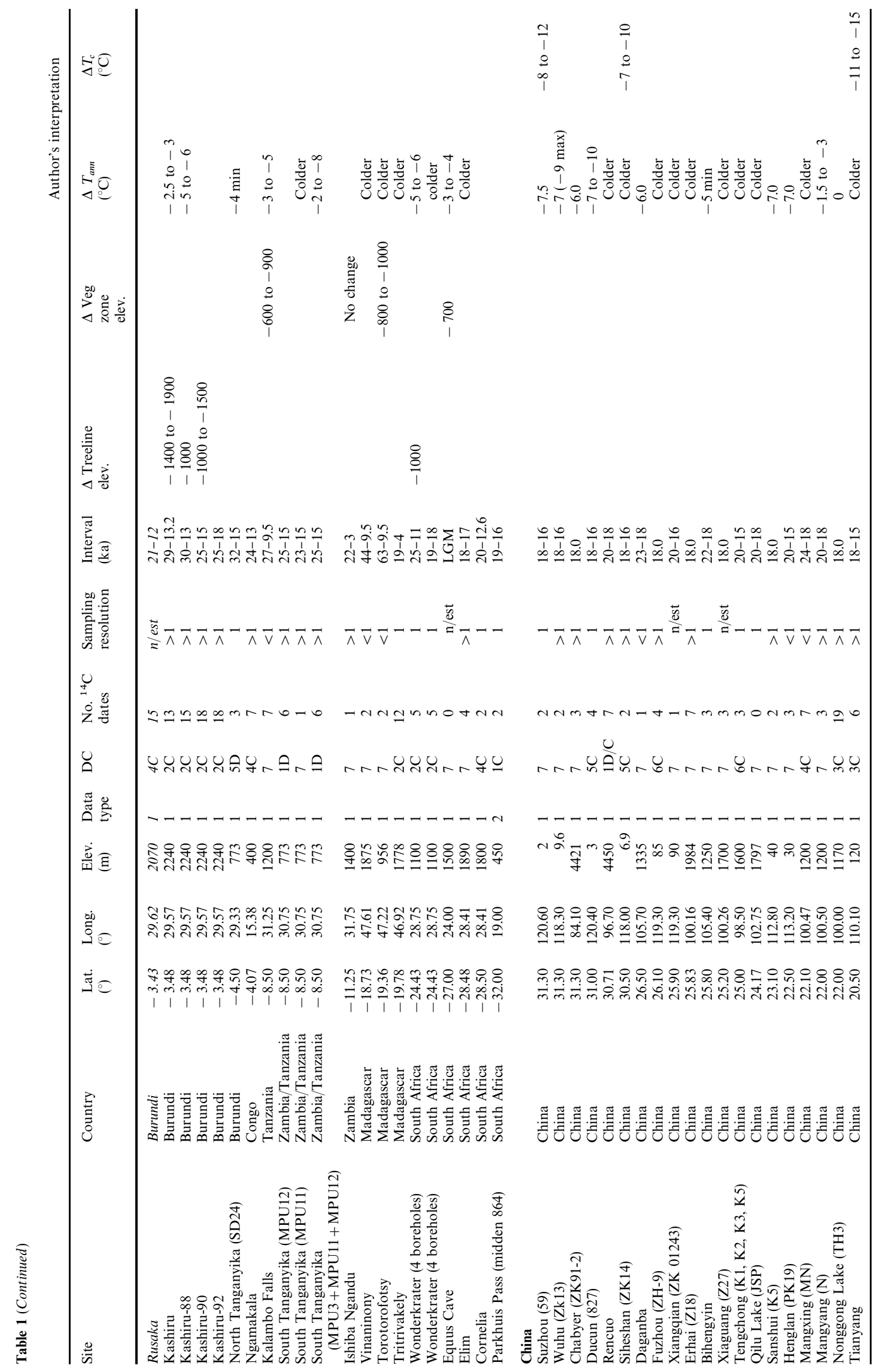




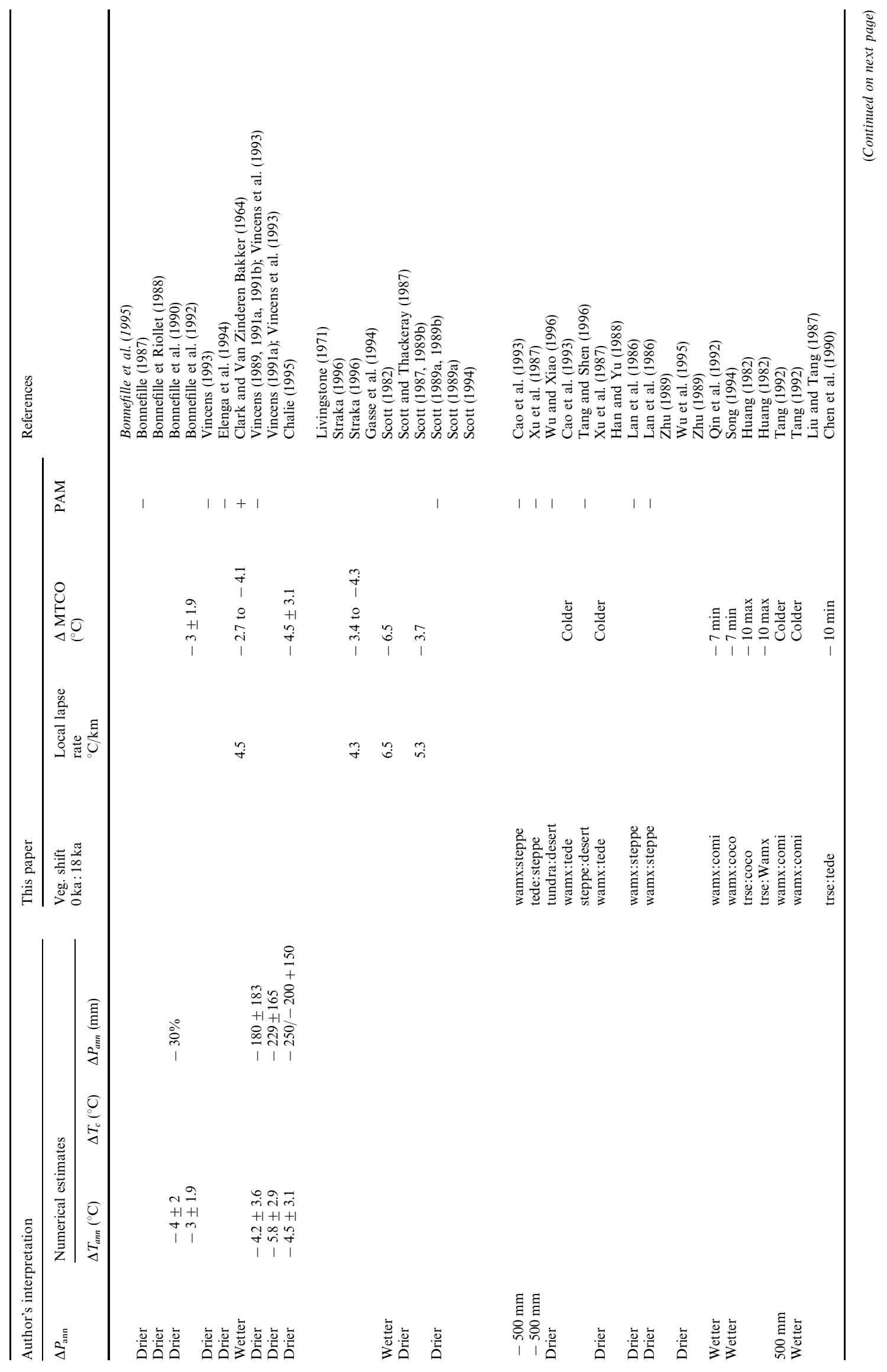




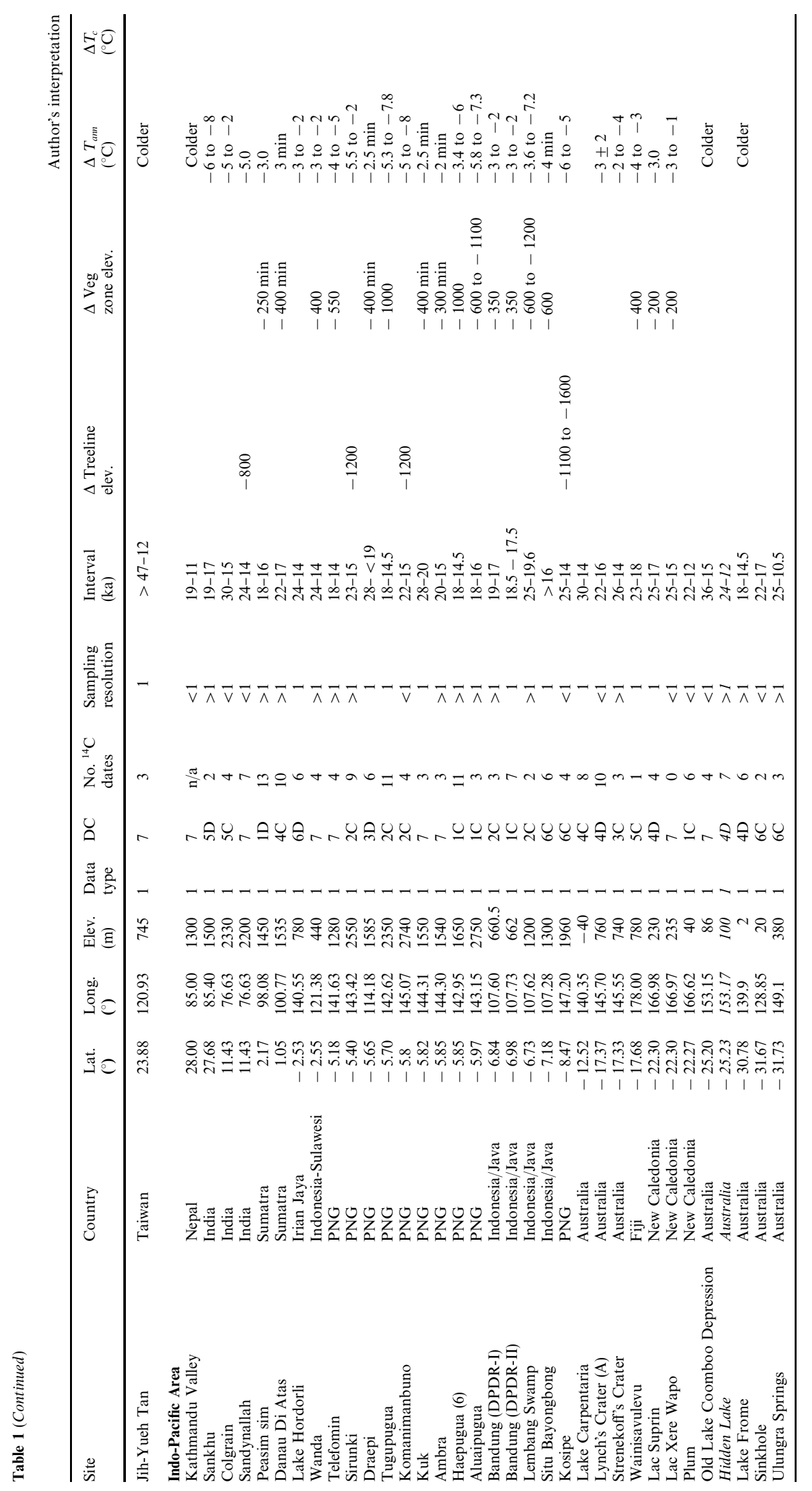




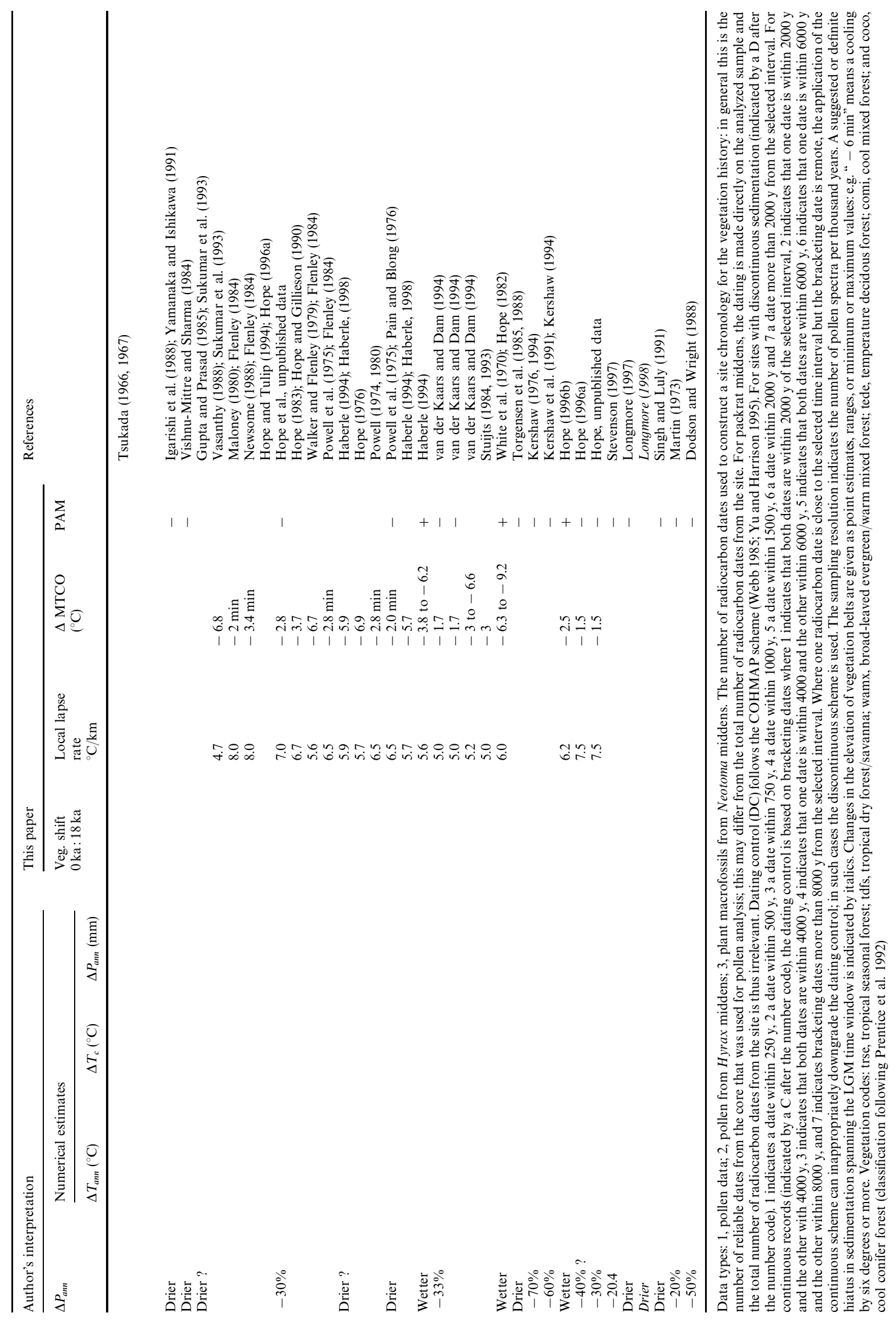


Published estimates of temperature changes from lowland or plateau regions are more commonly based on a modern-analog approach. The simplest of these approaches, which has been used for several sites from China, subjectively assigns a fossil pollen/macrofossil assemblage to a modern vegetation type and then assigns the climatic limits of the modern-day vegetation type to the fossil site. This approach makes two implicit assumptions: (a) that vegetation types are discrete and unchanging entities, and (b) that the limits of specific vegetation types are not controlled by specific aspects of the seasonal climate. As both of these assumptions are invalid, we do not consider temperature estimates based on this type of approach to be reliable. Instead, we have made an independent estimate of the temperature change between the LGM and the present day, based on the published descriptions of the changes in the pollen assemblages at each site. We first determined which plant functional types were represented in the fossil and modern samples, using the allocations of pollen taxa to plant functional types e.g. as given in $\mathrm{Yu}$ et al. (1998). We then estimated the change in temperature by comparing the minimum MTCO limits required by or the maximum MTCO limits tolerated by specific plant functional types on physiological grounds, as given in Prentice et al. (1992b). This method does not directly provide estimates of the change in MTCO, but rather provides bounding limits for such a change. These estimates, and the vegetation changes on which they were based, are listed in Table 1.

More advanced modern-analog approaches are based on optimising the climatic information that can be derived from the climate limits of individual species and/or plant functional types within a fossil pollen/macrofossil assemblage. Such methods require an extensive training set of modern samples and employ explicit numerical techniques, and thus make it possible (through an examination of uncertainties) to determine whether the reconstructed climatic variables are well constrained. In general, well-constrained reconstructions indicate that the reconstructed climatic variable controls the distribution of plants through some physical/physiological mechanism. We have retained those estimates made using explicit numerical methods (response surfaces in the case of the sites from eastern North America, direct search for analogs in the case of sites from Africa) which make use of the independent evidence offered by individual taxa in the pollen assemblage. In cases where multiple estimates have been made using statistical methods, we have retained the estimate based on the larger/largest modern training set. When using temperature reconstructions based on explicit statistical methods from the zone between $10^{\circ} \mathrm{N}$ and $10^{\circ} \mathrm{S}$, we have assumed that the reconstructed changes in MAT also apply to MTCO.

Estimates of MTCO anomalies are presented in three parallel maps (Fig. 2a-c). Point estimates (either from elevation shifts or from statistical methods) are given on one map. In order that the reliability of each estimate can be gauged visually, we have used the quoted errors $( \pm 2 \sigma)$ from the statistical methods to scale dot size in this map; the larger dots indicate the more reliable estimates. Where point estimates have been derived from elevation shifts we have applied a conventional error bar of $\pm<20 \%$. In many cases, however, elevation shifts are given as a minimum value, a maximum value, or a range of values. We have plotted the corresponding minimum and maximum cooling estimates on two separate maps.

3.2 Estimation of changes in MAT from noble gas and speleothem records

There are six noble gas records from old groundwaters within the study region (Fig. 1, Table 2); noble gas records obtained from three other tropical sites either pre- or post-date the LGM (Rudolf et al. 1984; Fontes et al. 1991; Andrews et al. 1994). These estimates of MAT have all been made with a consistent methodology, and can be regarded as reliable. Measurement errors are quoted as $\pm 2 \sigma$. The

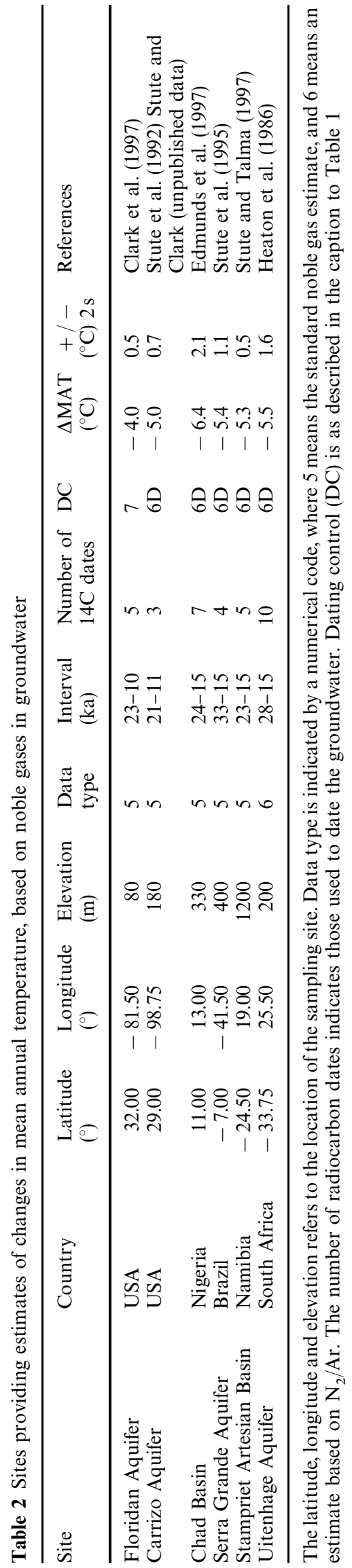


measurement errors are about \pm 0.5 to $1 \mathrm{~K}$ for most sites, but some (most notably the Chad Basin and Uitenhage aquifer) have quoted errors on the order of $\pm 2 \mathrm{~K}$. The central estimates of MAT anomalies are plotted on a single map (Fig. 2d) with dot sizes scaled by the error bars in the same way as for the point estimates of MTCO.

We have excluded all but one of the speleothem records of MAT (Table 3) because, in the absence of independent information on the $\delta^{18} \mathrm{O}$ composition of fossil cave seepage waters, they only provide qualitative estimates of changes in temperature. The speleothem record is temporally more highly resolved than the noble gas record from groundwater. We have therefore estimated the LGM temperature difference after applying a 1000-y moving average (comparable to the minimum interval over which the groundwater record is likely to be smoothed). We have computed a likely estimation error $( \pm 0.03 \mathrm{~K})$ on this value by recalculating the temperature change using a 5000-y moving average.

\subsection{Analysis of the relation between temperature anomalies and elevation}

We have analysed the estimates (a) of vegetation elevation shifts and (b) of change in MTCO (for sites that span a wide range of elevations) using ordinary least-squares linear regression, with site elevation as the predictor variable. As shown in the Appendix, MTCO changes are appropriately estimated from elevation shifts by using modern lapse rates, even if the lapse rates were different in the past. If elevation shifts are regressed against site elevation, the resulting intercept estimates the climatically induced elevation shift at modern sea level while the slope estimates the relative change in terrestrial lapse rate, if such a change occurred. If the MTCO estimates are regressed against site elevation, the intercept estimates the change in MTCO at modern sea level, and the slope estimates an absolute change in terrestrial lapse rate (see Appendix). We have calculated such regressions in two ways. In the main analyses we used only those sites for which point estimates of elevation shifts or temperature changes are available; this approach is likely a priori to give the most reliable results and proved in practice to fit the data best. As a check on the robustness and generality of the results we also performed regressions based on all estimates, including maximum and minimum estimates as independent data points.

Relationships between temperature anomalies and site elevation can be calculated from the entire data set to obtain approximate overall average estimates, or for subregions to investigate regional variations. We used such regional analyses to reduce the estimated MTCO and MAT changes to modern sea level taking into account inferred regional changes in lapse rate between LGM and present, as estimated by the regional regression slopes. This procedure reduces the data to a form best suited for comparison with the magnitudes and spatial patterns of changes in sea-surface temperatures (SSTs), as estimated from proxy data in marine sediments.

\subsection{Estimation of changes in PAM from pollen and plant macrofossil records}

The estimates of changes in moisture regimes at the LGM (Table 1) are based on observed present-day moisture requirements of individual plants in the fossil assemblage. Although most of the estimates of changes in moisture-balance parameters in the literature are referred to as changes in precipitation, they are better characterised as PAM. Given the difficulty in dissociating the potential effect of temperature and lowered $\left[\mathrm{CO}_{2}\right]$ from changes in precipitation, we assume that quantitative estimates of changes in PAM (or precipitation) are unreliable. It seems plausible to assume that the sign of the change in PAM is robust, however, and we include it here for comparison with the $P-E$ reconstructions.

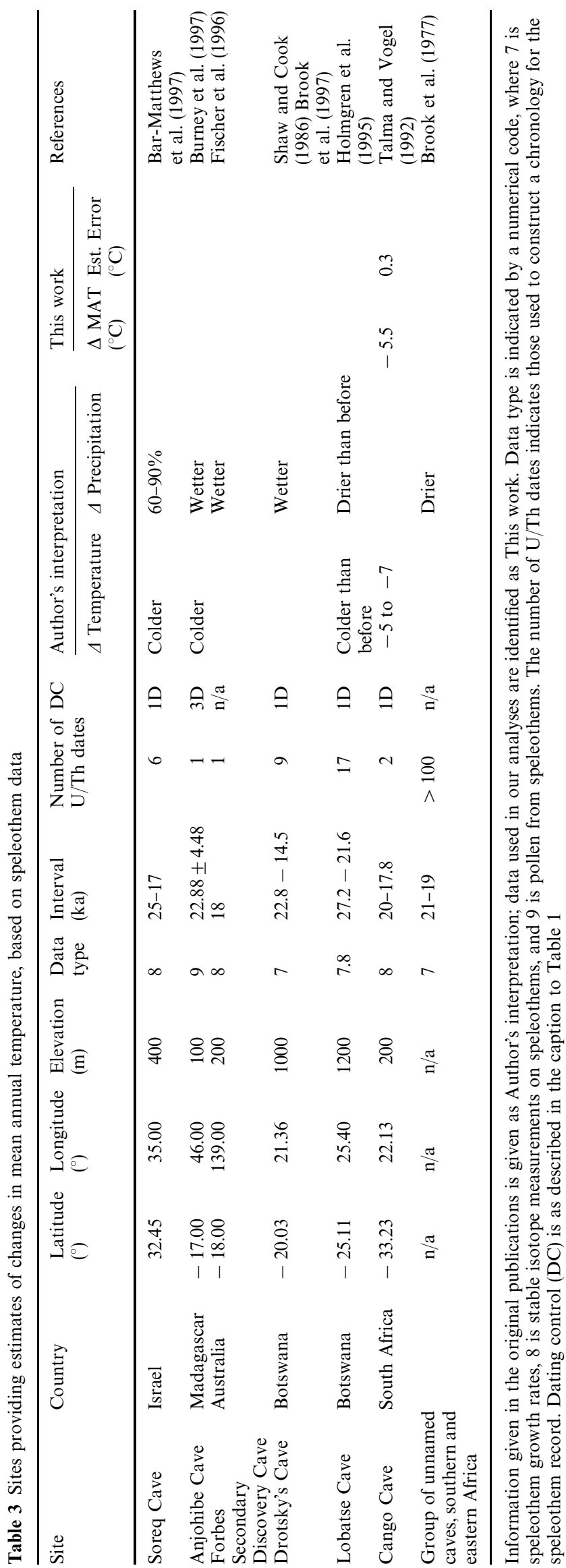


Table 4 Sites providing estimates of changes in mean annual $P-E$, based on lake status data

\begin{tabular}{llllll}
\hline Site & Country & $\begin{array}{l}\text { Latitude } \\
\left(^{\circ}\right)\end{array}$ & $\begin{array}{l}\text { Longitude } \\
\left(^{\circ}\right)\end{array}$ & $\begin{array}{l}\text { Elevation } \\
(\mathrm{m})\end{array}$ & $\begin{array}{l}\text { Number } \\
\text { of }{ }^{14} \mathrm{C} \\
\text { dates }\end{array}$ \\
\hline
\end{tabular}

\begin{tabular}{|c|c|c|c|c|c|c|c|}
\hline \multicolumn{8}{|l|}{ The Americas } \\
\hline Cochise & USA & 32.13 & -109.85 & 1260 & 35 & $1 \mathrm{D}$ & 1 \\
\hline Salt Basin & USA & 31.83 & -105.00 & 1087 & 5 & $1 \mathrm{C}$ & 1 \\
\hline Annie & USA & 27.30 & -81.40 & 36 & 9 & 7 & -1 \\
\hline Patzcuaro & Mexico & 19.58 & -101.58 & 2044 & 9 & $2 \mathrm{D}$ & -1 \\
\hline Chichancanab & Mexico & 19.50 & -88.75 & 38 & 4 & 7 & 0 \\
\hline Mexico & Mexico & 19.50 & -99.00 & 2240 & 26 & 7 & 0 \\
\hline Texcoco & Mexico & 19.45 & -99.00 & 2022 & 4 & $2 \mathrm{C}$ & 1 \\
\hline Wallywash & Jamaica & 17.95 & -77.80 & 7 & 11 & $6 \mathrm{D}$ & -1 \\
\hline Ciega & Colombia & 6.50 & -72.30 & 4000 & 3 & $3 \mathrm{C}$ & -1 \\
\hline Fuquene & Colombia & 5.50 & -73.75 & 2580 & 3 & $6 \mathrm{C}$ & -1 \\
\hline El Abra & Colombia & 5.00 & -74.00 & 2570 & 8 & $6 \mathrm{C}$ & 0 \\
\hline El Junco & Equador & -0.87 & -89.45 & 650 & 8 & 7 & -1 \\
\hline Titicaca & Peru/Bolivia & -16.00 & -69.25 & 3809 & 14 & $1 \mathrm{D}$ & 1 \\
\hline
\end{tabular}

\section{Middle East and Africa}

\begin{tabular}{|c|c|c|c|c|c|c|c|c|}
\hline Lisan/Dead Sea & Jordan/Israel & 31.50 & 35.50 & -395 & 45 & $3 \mathrm{D}$ & 1 & Street-Perrott et al. (1989) \\
\hline Saoura & Algeria & 30.00 & -2.00 & 400 & 20 & $6 \mathrm{D}$ & 1 & Street-Perrott et al. (1989) \\
\hline Kadda & Algeria & 26.20 & -0.88 & 250 & 3 & $2 \mathrm{D}$ & 1 & Street-Perrott et al. (1989) \\
\hline Nabta & Egypt & 23.00 & 31.00 & 250 & 33 & 7 & 0 & Street-Perrott et al. (1989) \\
\hline Bilma & Niger & 18.75 & 13.00 & 310 & 10 & 7 & 0 & Street-Perrott et al. (1989) \\
\hline Mundafan & S. Arabia & 18.53 & 45.42 & 870 & 32 & 7 & 0 & Street-Perrott et al. (1989) \\
\hline Fachi & Niger & 18.12 & 11.67 & 275 & 9 & 7 & 0 & Street-Perrott et al. (1989) \\
\hline Jebel Marra & Sudan & 13.00 & 24.23 & 2000 & 6 & 7 & 1 & Street-Perrott et al. (1989) \\
\hline Abhe & Ethiopia/Djibouti & 11.25 & 42.00 & 242 & 84 & $4 \mathrm{D}$ & 1 & Jolly et al. (1998a) \\
\hline Ziway-Shala & Ethiopia & 7.75 & 38.67 & 1558 & 52 & 7 & 1 & Street-Perrott et al. (1989) \\
\hline Bosumtwi & Ghana & 6.50 & -1.42 & 100 & 51 & $2 \mathrm{D}$ & -1 & Jolly et al. (1998a) \\
\hline Turkana & Kenya & 5.00 & 36.00 & 375 & 51 & 7 & 0 & Street-Perrott et al. (1989) \\
\hline Barombi-Mbo & Cameroon & 4.39 & 9.24 & 301 & 16 & $2 \mathrm{C}$ & -1 & Jolly et al. (1998a) \\
\hline Mobuto Sese Seko & Uganda/Zaire & 1.50 & 31.00 & 619 & 7 & $5 \mathrm{C}$ & 0 & Street-Perrott et al. (1989) \\
\hline Bogoria & Kenya & 0.30 & 36.10 & 990 & 33 & 7 & -1 & Jolly et al. (1998a) \\
\hline Nakuru-Elmenteita & Kenya & -0.42 & 36.17 & 1750 & 22 & $4 \mathrm{D}$ & -1 & Street-Perrott et al. (1989) \\
\hline Naivasha & Kenya & -0.68 & 36.33 & 1890 & 10 & $4 \mathrm{C}$ & 1 & Street-Perrott et al. (1989) \\
\hline Victoria & Uganda/Tanzania/Kenya & -1.00 & 33.00 & 1134 & 34 & $3 \mathrm{D}$ & -1 & Street-Perrott et al. (1989) \\
\hline Magadi & Kenya & -1.83 & 36.30 & 600 & 22 & $5 \mathrm{C}$ & 1 & Jolly et al. (1998a) \\
\hline Manyara & Tanzania & -3.62 & 35.82 & 945 & 14 & $1 \mathrm{C}$ & 1 & Street-Perrott et al. (1989) \\
\hline Tanganyika & $\begin{array}{l}\text { Burundi/Tanzania/ } \\
\text { Zambia/Zaire }\end{array}$ & -6.03 & 28.50 & 773 & 29 & $1 \mathrm{D}$ & -1 & Jolly et al. (1998a) \\
\hline Cheshi-Mweru Wantipa & Zambia & -8.87 & 29.68 & 928 & 4 & 7 & 0 & Street-Perrott et al. (1989) \\
\hline Malawi & Malawi & -12.00 & 34.50 & 622 & 25 & $6 \mathrm{C}$ & 1 & Jolly et al. (1998a) \\
\hline Alexandersfontein & South Africa & -28.83 & 24.80 & 1119 & 39 & $6 \mathrm{C}$ & 1 & Street-Perrott et al. (1989) \\
\hline Breek Been Kolk & South Africa & -30.80 & 20.10 & 800 & 1 & $6 \mathrm{C}$ & 1 & Street-Perrott et al. (1989) \\
\hline Haaskraal & South Africa & -31.42 & 24.37 & 1900 & 2 & 7 & -1 & Street-Perrott et al. (1989) \\
\hline \multicolumn{9}{|l|}{ Asia and Australia } \\
\hline Chabyer & China & 31.3 & 84.1 & 4421 & 3 & 7 & 1 & Qi and Zheng (1995) \\
\hline Frome & Australia & -30.75 & 139.83 & -2 & 46 & 7 & -1 & Harrison (1989) \\
\hline Storey's & Australia & -31.52 & 118.03 & 300 & 2 & $2 \mathrm{D}$ & 0 & Harrison (1989) \\
\hline
\end{tabular}

The quoted latitude and longitude are for a location in the approximate centre of the basin; the elevation is that of the modern lake surface, or the lowest elevation is the basin if there is no modern lake. The number of radiocarbon dates indicates those used to construct a site chronology for the lake-level history, usually the number of reliable dates from all sites in the basin. The number may therefore differ from the number given in Table 1 for the same site. Dating control (DC) is as described in the caption to Table 1

\subsection{Estimation of changes in $P-E$ from lake records}

Most of the data used to reconstruct $P-E$ changes (Table 4) are taken from the Oxford Lake-Level Data Base (OLLDB: Harrison 1988, 1989; Street-Perrott et al. 1989) or from the African Lake Status Data Base (ALSDB: Jolly et al. 1998a). These data bases use a consistent approach to the reconstruction of lake level records. Sites from the tropical Americas and China which have been published since the completion of the OLLDB have been coded for this study using the same approach. The coding scheme (low, intermediate, high) used by the OLLDB is less well resolved than the coding schemes used by more modern lake data bases, including the ALSDB. For this reason, as with PAM, we give only the sign of the inferred change in $P-E$.
We do not use evidence from lake sediments (for MTCO, PAM or $P-E$ ) at any site where there is unequivocal evidence of a sedimentary hiatus including the LGM. The occurrence of a hiatus is often used as evidence for a period when the lake basin was dry, implying low $P-E$ (e.g. Ledru et al. 1998). Without a detailed sedimentary analysis, however, one cannot tell whether such a hiatus was caused by drier conditions during the LGM, or the removal of LGM sediments during a postLGM dry phase (e.g. Street-Perrott and Harrison 1985). In a few cases where there may be a hiatus according to one interpretation of the stratigraphy, we have used the information, but Table 1 indicates the possible existence of a hiatus. 


\section{Results}

\subsection{MTCO}

The reconstructions of MTCO (Table 1, Fig. 2a-c) show a general lowering of temperature, with the majority of tropical sites cooling by -2 to $-6 \mathrm{~K}$. There is also some indication of geographic pattern. Relatively slight cooling by $\approx-2 \mathrm{~K}$ is shown consistently at sites on islands in the southern tropical Pacific. Relatively large cooling, by $\approx-5 \mathrm{~K}$ or more, is shown at numerous sites (including low-elevation sites) in the Neotropics (C and $\mathrm{S}$ America). Cooling by $-6 \mathrm{~K}$ or more is shown at some high-elevation sites.

The largest cooling is shown in the northern subtropics (Florida and southern China). In Florida, response-surface reconstructions of MTCO indicate winter temperature anomalies of -8 to $-15 \mathrm{~K}$ (Prentice et al. 1991; Webb et al. 1993). In southern China, cool conifer, cool mixed and temperate deciduous forests replaced the modern warm mixed and tropical evergreen forests at the LGM (Yu et al. unpublished data). Reconstructions based on the cold-tolerance limits of plant types represented in the pollen spectra from southeastern China yield estimates of the LGM temperature anomaly of at least -7 to $-10 \mathrm{~K}$. Note that these are cold-month anomalies, which at subtropical latitudes need not resemble MAT anomalies because of the seasonality of the temperature regime.

\subsection{MAT}

Seven published sites to date provide reliable estimates of the change in mean annual ground temperature at the LGM (Fig. 2d), but only two of these (Chad Basin, Serra Grande Aquifer) lie in the tropics sensu stricto. The data indicate a lowering in MAT in the recharge zones of each catchment in the range $\approx-4$ to $-6 \mathrm{~K}$. The range of MAT anomaly estimates is thus less than the range of MTCO anomaly estimates. However, there are no geochemical MAT estimates e.g. from the Pacific islands or Indonesia that could be compared with the relatively small MTCO anomaly estimates obtained there. Thompson et al. (1995) inferred a larger annual cooling of -8 to $-12 \mathrm{~K}$ from $\delta^{18} \mathrm{O}$ measurements in a low-latitude ice core at about $6000 \mathrm{~m}$, which is consistent with our finding of larger MTCO anomalies at higher elevations.

MAT and MTCO estimates diverge markedly only in the northern subtropics, where MAT anomalies continue to be around -4 to $-6 \mathrm{~K}$, while MTCO estimates of the cooling are $-8 \mathrm{~K}$ or larger. A simple hypothesis to explain this divergence is that greater cooling in the winter season is produced by advection of cold air from the adjacent continents.

\subsection{Temperature anomalies and elevation}

When reported elevation shifts of vegetation belts are regressed against the elevation of the site at which each shift was estimated (Fig. 3; Table 5), it becomes clear that the magnitude of these shifts increases systematically with height above modern sea level. The correlation between elevation change and modern elevation (based on point estimates) is 0.45 for the whole study region, rising to 0.53 when only the equatorial belt $\left(15^{\circ} \mathrm{S}-15^{\circ} \mathrm{N}\right)$ is considered. The corresponding regressions are significant $(P<0.02)$. The estimated average vegetation zone depression is $-500 \mathrm{~m}$ (or $-465 \mathrm{~m}$ for the equatorial belt) at modern sea level with $-0.19 \mathrm{~m}$ $(-0.24 \mathrm{~m}$ for the equatorial belt) additional lowering for each $1 \mathrm{~m}$ increase in elevation. The minimum and maximum estimates tend to bracket the main regression line, and there is no systematic relationship between site elevation and the residuals from the regression, indicating that the linear regression representation is appropriate for these data. The regression relationship for all sites remains significant $(P \leq 0.01)$ when all of the data, including maximum and minimum estimates, are used. The estimated vegetation zone depression is somewhat larger $(-720 \mathrm{~m})$ and possibly inflated by the inclusion of high maximum estimates, while the estimated increase with elevation is somewhat smaller $\left(-0.11 \mathrm{~mm}^{-1}\right)$.

Estimated MTCO anomalies tell essentially the same story. The data used for these analyses also include statistical estimates of change in MTCO, but they exclude estimates from the areas of extreme winter cooling in Florida and south China. The analyses based on point estimates give $r=0.44$, rising to 0.48 when only the equatorial belt is considered, and are significant $(P \approx 0.02)$. The regression indicate an average cooling at modern sea level by $-2.9 \mathrm{~K}(-2.8 \mathrm{~K}$ for the equatorial belt) with lapse rates overall steeper by $0.8(0.79$ for all sites, 0.81 for the equatorial belt) $\mathrm{K} \mathrm{km}^{-1}$. Regressions including all estimates are again significant $(P<0.002$ and $<0.02$ for all sites and the equatorial band respectively) and similar to the regressions based on point estimates, although the estimated cooling at modern sea level is slightly larger $(-3.6$, or $-3.9 \mathrm{~K}$ for the equatorial belt) and the estimated lapse rate increase is somewhat larger $\left(-0.9\right.$, or $-0.8 \mathrm{~K} \mathrm{~km}^{-1}$ for the equatorial belt).

The estimates based on treeline lowering, which could in principle be influenced by low $\left[\mathrm{CO}_{2}\right]$, do not systematically depart from these regressions (Fig. 3). When sites reflecting treeline changes are removed from the analyses, the significance of the regressions is reduced to $P<0.4$ (due mainly to the insufficient sample size) yet the estimated regression slopes and intercepts remain almost identical: we estimate a depression at modern sea level by $-510 \mathrm{~m}$ increasing by $-0.18 \mathrm{~m}$ per $1 \mathrm{~m}$ of height, or a MTCO reduction at modern sea level of $-3.0 \mathrm{~K}$ increasing by 

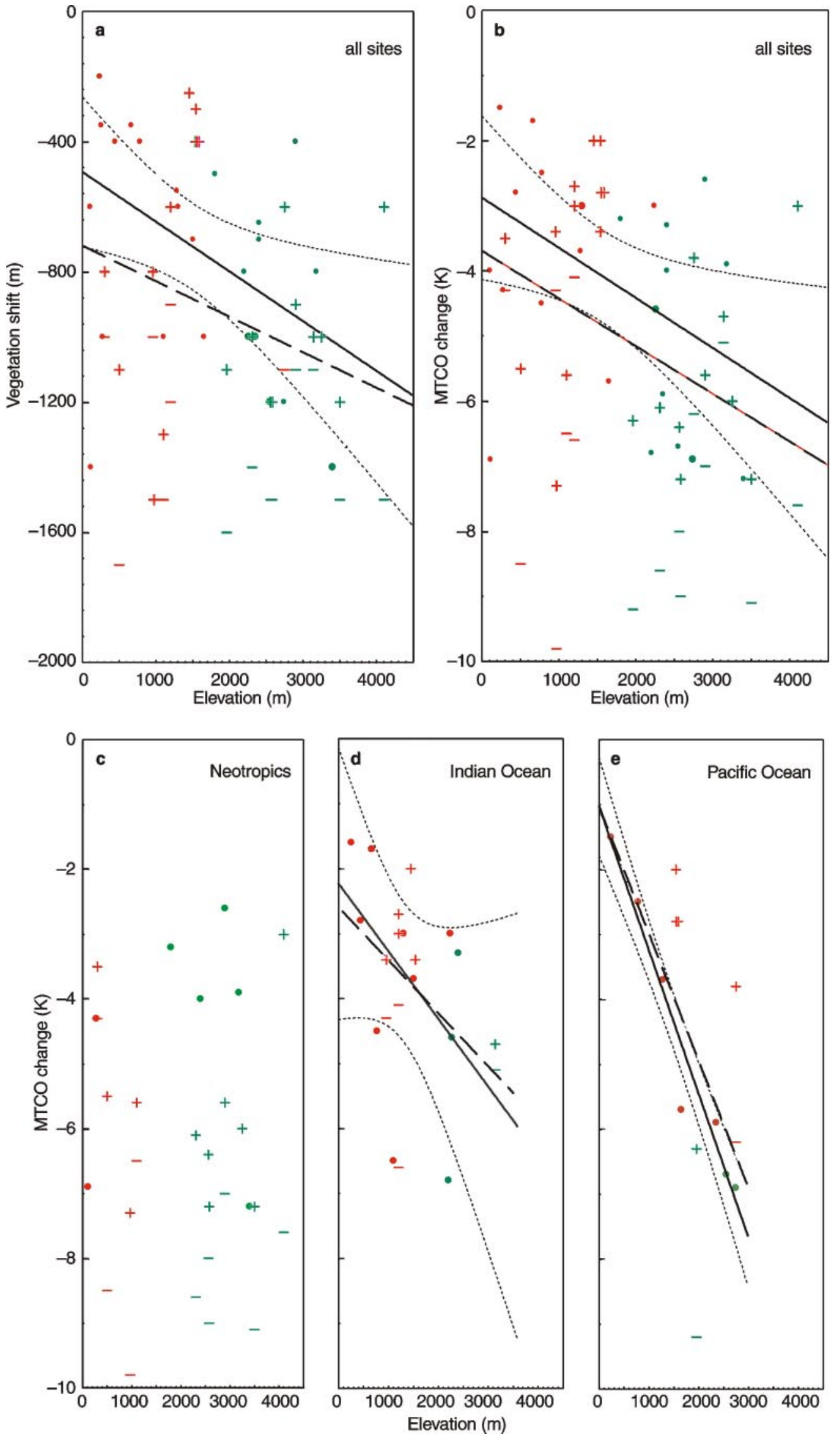
Table 5 Dependence of cold-month temperature (MTCO) anomalies on elevation: summary of regression results. Slope estimates given in parentheses are non-significant $(P>0.05) . \Delta h(0)$ is estimated change in vegetation zone elevations at modern sea level; $\Delta T(0)$ is estimated change in MTCO at modern sea level; $n$ is number of points; $r$ is correlation coefficient; $P$ is probability of the null hypothesis, i.e. no elevation effect

Results based on point estimates

Elevation shifts

MTCO anomalies

\begin{tabular}{cccccccrrr}
\hline $\begin{array}{c}\Delta h(0) \\
(\mathrm{m})\end{array}$ & $\begin{array}{l}\text { Slope } \\
\left(\mathrm{m} \mathrm{m}^{-1}\right)\end{array}$ & $n$ & $r$ & $P$ & $\begin{array}{l}\Delta T(0) \\
(\mathrm{K})\end{array}$ & $\begin{array}{c}\text { Slope } \\
\left(\mathrm{K} \mathrm{km}^{-1}\right)\end{array}$ & $n$ & $r$ & $P$ \\
\hline-493 & -0.19 & 26 & 0.45 & 0.019 & -2.88 & -0.79 & 28 & 0.44 & 0.018 \\
-465 & -0.24 & 19 & 0.53 & 0.020 & -2.81 & -0.81 & 21 & 0.48 & 0.028 \\
-512 & $(-0.18)$ & 13 & 0.26 & 0.400 & -2.99 & $(-0.60)$ & 15 & 0.26 & 0.350 \\
-1063 & $(0.09)$ & 7 & 0.31 & 0.510 & -5.09 & $(0.25)$ & 7 & 0.19 & 0.680 \\
-315 & -0.24 & 10 & 0.74 & 0.010 & -2.23 & $(-1.04)$ & 12 & 0.47 & 0.120 \\
-107 & -0.18 & 8 & 0.98 & $<0.001$ & -1.03 & -2.21 & 8 & 0.98 & $<0.001$
\end{tabular}

\section{All sites ${ }^{\mathrm{a}}$}

Equatorial belt only

Non-tree line only

Neotropical region

Indian Ocean region

$-0.18$

0.98

$<0.001-1.03$

$-2.21$

0.120

Results based on point, maximum and minimum estimates Elevation shifts

MTCO anomalies

\begin{tabular}{cccccccccr}
\hline $\begin{array}{c}\Delta h(0) \\
(\mathrm{m})\end{array}$ & $\begin{array}{c}\text { Slope } \\
\left(\mathrm{m} \mathrm{m}^{-1}\right)\end{array}$ & $n$ & $r$ & $P$ & $\begin{array}{c}\Delta T(0) \\
(\mathrm{K})\end{array}$ & $\begin{array}{c}\text { Slope } \\
\left(\mathrm{K} \mathrm{km}^{-1}\right)\end{array}$ & $n$ & $r$ & $P$ \\
\hline-721 & -0.11 & 64 & 0.28 & 0.002 & -3.62 & -0.92 & 66 & 0.37 & 0.002 \\
-796 & $(-0.08)$ & 55 & 0.20 & 0.140 & -3.94 & -0.84 & 57 & 0.31 & 0.020 \\
-834 & $(0.03)$ & 34 & 0.04 & 0.840 & -4.05 & $(-0.22)$ & 36 & 0.05 & 0.790 \\
-1287 & $(0.06)$ & 24 & 0.19 & 0.330 & -6.01 & $(-0.24)$ & 28 & 0.06 & 0.770 \\
-434 & -0.19 & 22 & 0.52 & 0.020 & -2.59 & -0.80 & 22 & 0.42 & 0.050 \\
-106 & -0.37 & 15 & 0.71 & $<0.001$ & -1.06 & -1.99 & 15 & 0.71 & $<0.001$ \\
\hline
\end{tabular}

\section{All sites ${ }^{\mathrm{a}}$}

Equatorial belt only

Non-tree line only

Neotropical region

Indian Ocean region

Pacific Ocean region

$-106$

${ }^{\text {a }}$ Excluding S China, SE USA.

$-0.6 \mathrm{~K} \mathrm{~km}^{-1}$. Thus, the relationships with elevation are not wholly dependent on treeline shifts, and the observed treeline shifts conform to the same pattern as the shifts of vegetation zones at lower elevations.

Inspection of the spatial patterns in Fig. 2 suggests however that the cooling was not spatially homogeneous, even at constant elevation. Some of the scatter around the global regression lines might be due to geographic variations in the sea-level cooling, in the relationship with elevation, or both. We therefore performed separate analyses for three regions defined a priori as follows: the Neotropical region, represented by records from Central America and the northern part of South America; the Indian Ocean region, repre-

Fig. 3a-e Cooling as a function of site elevation: a uncorrected elevation shifts: all data; $\mathbf{b}$ estimated cold-month anomalies: all data including statistical estimates, but excluding northern subtropics; $\mathbf{c}-\mathbf{e}$ as $\mathbf{b}$ but for Neotropical region, Indian Ocean region, Pacific Ocean region. Fitted lines are least-squares linear regressions (Table 5). Solid lines and curve envelopes refer to regressions based on point estimates; dashed lines to regressions based on all estimates. Symbols:

- point estimates, + minimum estimates (i.e. smallest cooling), - maximum estimates (i.e. greatest cooling), Symbols in green are for sites where the elevation change refers to the upper forest limit (treeline) and those in red to non-treeline sites sented by records from South and East Africa, India and Indonesia; and the Pacific Ocean region, including Papua New Guinea and Pacific island sites (Fig. 3; Table 5). Thus partitioned, the data show considerable geographic patterning both in the sea-level temperature change estimates and in the implied changes in lapse rate. For the Neotropical region, we estimate the largest vegetation zone depression $(-1100 \mathrm{~m})$ and cooling $(-5.6$ to $-5.7 \mathrm{~K})$ with no significant elevation effect. For the Indian Ocean region, the estimates are similar to those for the data set as a whole: -2.2 to $-2.6 \mathrm{~K}$ cooling at modern sea level, increasing by -0.8 to $-1.0 \mathrm{~K} \mathrm{~km}^{-1}$, with $r=0.42$ to 0.47 and $P=$ 0.12 (for point estimates) or 0.05 (for all estimates). For the Pacific Ocean region, we estimate the smallest cooling $(-1.0$ to $-1.1 \mathrm{~K})$ at modern sea level, increasing by -2.0 to $-2.2 \mathrm{~K} \mathrm{~km}^{-1}$, with $r=0.98$ for point estimates, $r=0.71$ for all estimates, and high significance $(P<0.001)$ in both analyses.

These regional differences in sea-level cooling can be seen in Fig. 2a-c, but are partially confounded by the proximity of sites at very different elevations. This confounding of geographic and elevation effects is most marked in Indonesia and Papua New Guinea. The geographic patterns are brought out more clearly in Fig. 4, where the estimated MTCO and MAT anomalies from sites at $<1500$ m elevation have been reduced to modern sea level using the main regional 

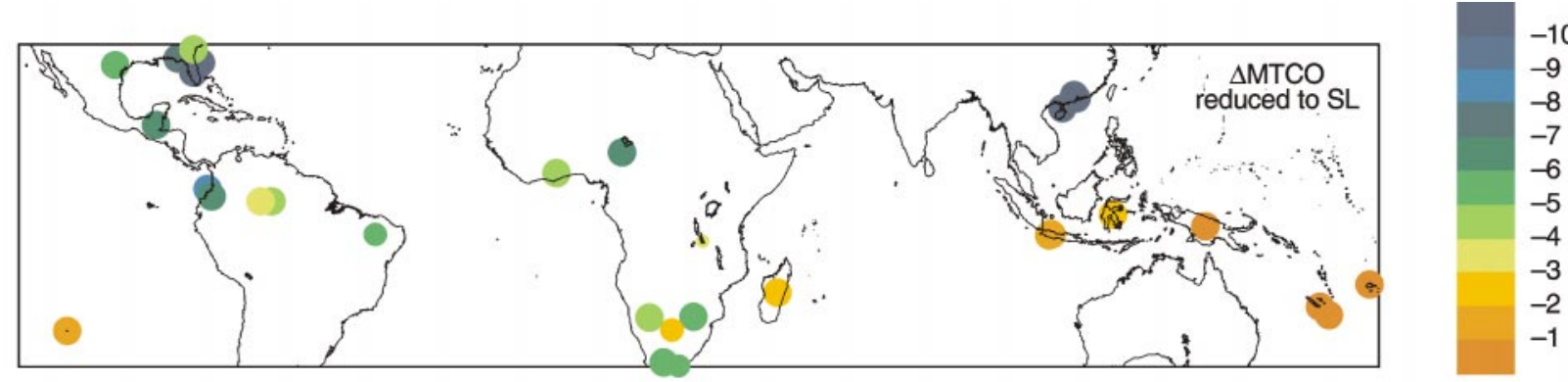

Fig. 4 Estimated temperature anomalies (MTCO or MAT) at modern sea-level based on sites at elevation $<1500 \mathrm{~m}$, for comparison with sea-surface conditions. Sites for which only a maximum or a minimum estimate of the temperature change is available are not included on this map, with the exception of three sites from the same region of southern China. Vegetation changes at each of these three sites yield either a maximum or a minimum estimate of $-10 \mathrm{~K}$, indicating that the actual change was very close to this value. A temperature correction is made for sites in the Indian Ocean and Pacific Ocean regions, using the slope coefficients (slope, $\mathrm{K} \mathrm{km}^{-1}$ ) based on point estimates in Table 5

a

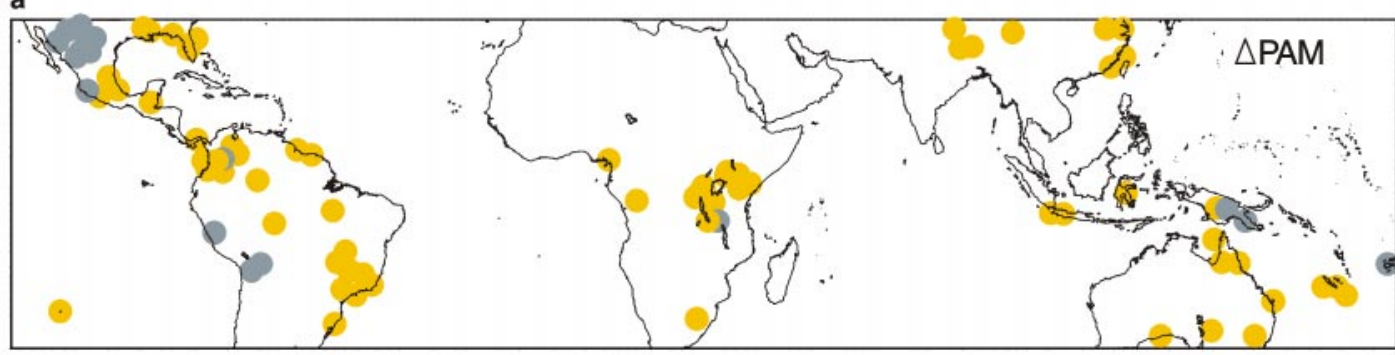

b

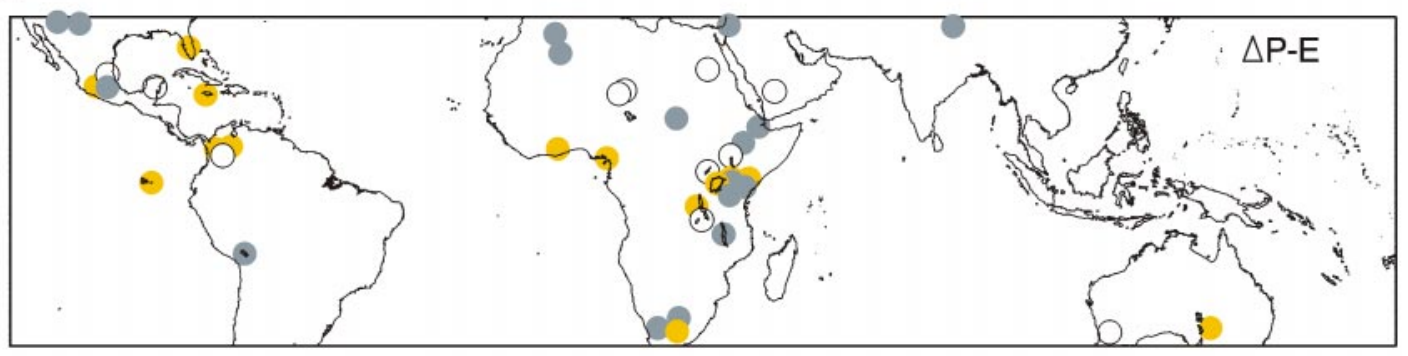

same

less

Fig. 5 a Directions of change in plant-available moisture (PAM) inferred from pollen and plant macrofossil data; $\mathbf{b}$ directions of change in precipitation minus evapotranspiration $(P-E)$ inferred from lake level reconstructions

regression results. (Sites outside the regions are shown without reduction to sea level. Any such reduction would have little effect because these sites are all at low elevations.) The smaller estimates of sea-level cooling, are associated with the southern tropical Pacific and regions bordering the Indian Ocean while larger estimates characterize the northern Neotropics, West Africa and the northern subtropics, indicating a strong geographic pattern that might be related to geographic variation in SSTs.

\subsection{PAM}

Eighty sites provide qualitative records of the change in PAM between the LGM and present. PAM was apparently less than today across most of the tropical zone (Fig. 5). Only three regions show conditions wetter than today: the now-arid regions of western North America, high elevation sites in the Andean Altiplano, and sites in montane Papua Guinea. However, there are large areas (e.g. northern Sahara 
and the Middle East) without information about changes in PAM.

\section{5 $P-E$}

Forty lake sites record qualitative changes in mean annual $P-E$ between the LGM and present (Fig. 5). A more positive mean annual $P-E$ is recorded in the now-arid basins of western North America, and on the southern Andean Altiplano. Records from the central Sahara suggest that conditions were as dry as today. High lake levels in the northwestern Sahara (Conrad 1969; Causse et al. 1988) may reflect problems in the interpretation or dating of the sites involved but, given that lakes in the Mediterranean region were high (Prentice et al. 1992a; Harrison and Digerfeldt 1993) and that sites in the Middle East also indicate a more positive $P-E$ (Roberts and Wright 1993), it seems possible that these lakes are fed by runoff from the Atlas mountains and are thus registering conditions unrelated to the local climate (Street-Perrott et al. 1989).

Otherwise, $P-E$ was less than today across the tropics, from central America into western Africa. In equatorial East Africa the lakes show conditions similar or drier than present to the west of about $34^{\circ} \mathrm{E}$ and similar or wetter than present to the east. A site from the Tibetan plateau registers a more positive $P-E$ balance than today. Some sites from southern Africa imply a more positive $P-E$ than today, but the single site from the Australian subtropics registers drier conditions.

Data on PAM and $P-E$ are to some extent complementary in terms of the regions included, and this gives rise to a superficial difference between the maps. However, in areas where both types of data exist, the direction of change is almost consistently the same in both. A possible exception is the Tibetan plateau, where preliminary results from further sites confirm high lake levels while pollen evidence suggest lower than present PAM.

The sites showing wetter conditions than present in the tropics sensu stricto, either in PAM or in $P-E$, are all at high elevations. This suggests that strong cooling at high elevations might have disproportionately reduced atmospheric evaporative demand, leading to increased $P-E$.

\section{Discussion and conclusions}

\subsection{Temperature changes}

MAT and MTCO are expected to vary in broadly similar ways at low latitudes because of the low seasonality of insolation at low latitudes, which offers limited scope for changes in temperature seasonality.
Yet the estimates from different types of data need not a priori agree since they have different sensing characteristics. In particular, the temporal smoothing inherent in the noble gas technique means that estimates of MAT obtained with this technique may include a component due to extreme events occurring in a broad temporal interval, possibly even including Heinrich events. In the mid-latitudes, MAT and MTCO anomalies could more easily diverge as the summer and winter temperature regimes there are fundamentally different. We find a systematic difference between estimated MAT and MTCO anomalies in the northern subtropics (Fig. 2). However, in the tropics sensu stricto and in the southern subtropics the MAT estimates do not systematically differ from the MTCO estimates. The one speleothem MAT estimate (in southern Africa) resembles the nearby noble-gas MAT and MTCO estimates, despite the differences in the sensing characteristics of the three data.

The geochemical estimates of MAT lowering give the superficial impression of a relatively uniform tropical and subtropical cooling by -4 to $-6 \mathrm{~K}$, whereas the pollen-based estimates of MTCO lowering vary more widely. However there are no demonstrable inconsistencies between the two types of record, except in the northern subtropics. The MTCO estimates are more numerous and spread across a wider range of modern environments. Relatively slight cooling is shown by pollen data from regions adjoining the Indian Ocean and from islands in the southern Pacific, while large cooling is shown at high elevations in all regions. There are as yet no geochemical estimates from the regions where the MTCO estimates show only slight cooling. Nor are there geochemical estimates from high elevations, apart from the ice-core estimate of Thompson et al. (1995) from $>6000 \mathrm{~m}$. This ice-core estimate supports our finding of extreme cooling at very high elevations, even though the MTCO data from the Neotropics show no significant dependence on elevation in the lower elevation range $(0-3500 \mathrm{~m})$.

In the northern subtropics, there is a marked divergence of winter temperature anomalies from the MAT anomalies. A simple explanation is that winters were cooled by much more than the other seasons, due to enhanced advection of anomalously cold air from the continental interiors. This explanation is consistent with PMIP model results that consistently show large wintertime cooling of both the interior of North America and E Asia (Pinot et al. this volume). Quantitative reconstructions of MTCO lowering by -15 to $-19 \mathrm{~K}$ have also been derived from sites at about $35^{\circ} \mathrm{N}$ in the Mediterranean region, suggesting a similar climatological explanation for extreme cooling in Europe (Peyron et al. 1998).

A robust feature of the MTCO reconstructions is their dependence on elevation, particularly in the Palaeotropics (Fig. 3). Taking this elevation effect into account, we estimate that tropical temperatures were 
depressed by on average $-2.9 \mathrm{~K}$ at modern sea level. After reducing the estimated temperature anomalies to modern sea level using regional relationships between MTCO anomalies and elevation, we obtain a more spatially coherent geographic pattern (Fig. 4) allowing us to estimate that the southern tropical Pacific and lowland regions bordering the Indian Ocean cooled by $-2 \mathrm{~K}$ or less while lowland Central and South America and regions bordering the tropical Atlantic cooled by -4 to $-6 \mathrm{~K}$. This finding is consistent with the conclusions of Colinvaux et al. (1996) concerning the Neotropics, while indicating that cooling in other tropical lowland regions was less dramatic.

\subsection{Land-ocean connections}

CLIMAP Project Members (1981) showed that there were important regional differences in the magnitude of sea-surface cooling at the LGM, and specifically that there were some tropical oceanic regions where the cooling was small or where the reconstructions imply conditions warmer than present (including the southern Pacific gyre). However, Broccoli and Marciniak (1996) have pointed out that the warm tropical Pacific reconstruction in CLIMAP relies on cartographic extrapolation from a few data points with high uncertainty. Our reconstructions of temperature anomalies reduced to sea level (Fig. 4) also show geographic structure. This structure is moreover consistent in certain important qualitative respects with geographic patterns shown in the CLIMAP (1981) reconstruction and in the original CLIMAP data set (Broccoli and Marciniak 1996). In particular, the areas of weak cooling (or warming) shown by CLIMAP for the southern Pacific and northern Indian Oceans agree qualitatively with our estimates of relatively slight cooling at sea level on adjacent land areas, while the stronger cooling shown by CLIMAP in the Caribbean and eastern subtropical Pacific agrees qualitatively with the evidence for relatively large cooling at sea level in Central America.

The average sea-surface cooling implied by the reconstructions from CLIMAP Project Members (1981) is only $\approx-1.5$. Several recent studies however have suggested that tropical SST anomalies at the LGM must have been colder, perhaps by several degrees, than originally reconstructed by CLIMAP (Anderson and Webb 1994; Webb et al. 1997). Studies based on reexamination of the foraminiferal data (Prell et al. 1996; Anderson and Webb 1998), stable isotopes in foraminifera (Patrick and Thunell 1997), $\mathrm{Sr} / \mathrm{Ca}$ ratios in corals (Guilderson et al. 1994) and alkenone palaeothermometry (Sikes and Keigwin 1994; Bard et al. 1997, 1998) have all indicated a tropical ocean surface colder than CLIMAP. Some studies have implied that there was a general cooling of the tropical ocean by as much as $-5 \mathrm{~K}$ (e.g. Guilderson et al.
1994). The terrestrial data clearly support the view that the tropical ocean surface at the LGM was colder than indicated by the CLIMAP reconstruction (Stute et al. 1995). At the same time, the data limit the plausible magnitude of the cooling, especially when the effect of lowered sea level $(-120 \mathrm{~m})$ is taken into account. This lowering itself implies that any point on the present land surface would be cooled by about $-0.5 \mathrm{~K}$, even if SSTs did not change. Thus, the terrestrial data imply that the tropical average SST anomaly was only about -2 to $-2.5 \mathrm{~K}$. This inference is consistent with the average LGM cooling of the tropical ocean as reconstructed from alkenone palaeothermometry (Bard et al. 1998).

Our estimate of the tropical average SST anomaly is consistent with results from coupled atmosphere-ocean models of "intermediate complexity" (Ganopolski et al. 1998; Weaver et al. 1998). The PMIP simulations with mixed-layer ocean models tend to fall into two classes: those that produce a uniform tropical cooling by $\approx-5 \mathrm{~K}$ or more, and those that cool the tropical ocean in global average by about the same as the CLIMAP reconstruction or by a further $\approx-1 \mathrm{~K}$. Within the latter class, some models are better able to reproduce the spatial patterns of cooling suggested by the terrestrial data (Pinot et al. this volume). The coupled atmosphere-ocean dynamic simulation by Bush and Philander (1998) also shows spatial patterns that are broadly consistent with the terrestrial data, with anomalies of $\approx-2 \mathrm{~K}$ in the southern Pacific and Indian Oceans contrasting with $\approx-4$ to $-6 \mathrm{~K}$ in the Pacific to the west of Central America and the northern part of South America. Comparable features are shown by the coupled model used by Weaver et al. (1998), which includes a full three-dimensional ocean model.

\subsection{Water balance}

The two independent, qualitative indicators of change in water balance, PAM based on palaeoecological records and $P-E$ based on lake level records, like the various temperature indicators are not necessarily congruent a priori but appear to be so on the basis of the mapped observations within the region of study. Thus, the changes in PAM and $P-E$ are both positive in western North America and on the Andean Altiplano. They are both negative in the equatorial zone of the Americas and western Africa, and in Australia. Although the PAM and $P-E$ anomaly maps (Fig. 5) appear different at first glance, this reflects the fact that there are very few estimates of PAM in regions that are arid today and were wetter at the LGM.

The agreement between PAM and $P-E$ is consistent with a simple hypothesis that the tropical land areas received less precipitation annually, while the southward shift of the jet stream (COHMAP Members 1988; Kutzbach et al. 1993; Kutzbach et al. 1998) brought 
increased precipitation to the southwestern USA. The apparent wetness of high elevations may be due to strong cooling, reducing evaporative demand more than any increase in precipitation at these elevations. Generally reduced precipitation in the tropics and subtropics and enhanced precipitation in the path of southward-shifted jet streams in the Northern Hemisphere are also consistent features of PMIP simulations for the LGM (Pinot et al. this volume).

\subsection{Possible causes of anomalous temperature-elevation relationships}

Several Quaternary scientists have discussed the hypothesis that tropical lapse rates might have been steeper at the LGM than today (e.g. Van der Hammen 1974, 1991; Walker and Flenley 1979; Bakker 1990; Van der Hammen and Absy 1994). The hypothesis was proposed initially to explain an apparent discrepancy between CLIMAP $(1976,1981)$ tropical SST estimates for the LGM and the evidence for ELA depressions of $1000 \mathrm{~m}$ or more in tropical mountain regions. Reconciliation of these two sets of observations in physical terms has proved challenging (Rind and Peteet 1985; Webster and Streten 1978; Broecker and Denton 1990; Rind 1990; Betts and Ridgway 1992).

The MTCO data compiled here indicate that the effective (i.e. terrestrial) lapse rates at the LGM were indeed steeper than present in some regions, although there is insufficient evidence for this effect in the Neotropics. A complete treatment of possible mechanisms behind altered temperature-elevation relationships must take account of ELA data as well as vegetation shifts, because the use of both types of information provides additional constraints on the vertical profiles of precipitation and atmospheric water vapour content (Broecker and Denton 1990; Broecker 1997). A great deal of new information on ELA shifts has also come into existence during the last decade (e.g. Ono 1988; Schubert and Clapperton 1990; Rodbell 1992; Fox and Bloom 1994; Helmens et al. 1996; Sharma and Owen 1996; Thouret et al. 1996; Ono and Naruse 1997). Compilation of tropical ELA data is underway, and will form the subject of a separate review (Part II of this synthesis). Here we draw attention to a variety of observations and model results that make increased terrestrial lapse rates at LGM a physically plausible possibility.

1. Thermodynamic considerations dictate that the moist adiabatic lapse rate steepens as surface temperature is lowered (e.g. Hartmann 1994, p. 354; Betts and Ridgway 1992), and free-air lapse rates in the tropics are often close to the moist adiabatic rate (Webster and Streten 1978). Given an ocean surface colder than CLIMAP, the thermodynamic effect should be stronger than was estimated by Rind and Peteet (1985) based on CLIMAP SSTs. Indeed, Rind and Peteet (1985) found that an artificial lowering of tropical SSTs by $2 \mathrm{~K}$ relative to the CLIMAP reconstruction produced significantly steeper lapse rates than in their "standard" LGM experiment. Webb et al. (1997), using the GISS atmospheric model coupled to a mixed layer ocean model, simulated a substantial LGM cooling of the tropical ocean, also accompanied by a significant increase in lapse rate.

2. Observations on the relationship between freezing heights and SST anomalies (Diaz and Graham 1996) indicate a sensitivity of as much as $600 \mathrm{~m}$ (equivalent to $3-5 \mathrm{~K}$ at $\approx 6000 \mathrm{~m}$ elevation) for each $1 \mathrm{~K}$ change at the surface. This result implies an amplification of changes in temperature at the surface of a similar order to that which we infer from the palaeodata. Diaz and Graham (1996) tentatively attribute the amplification to a tendency for warmer sea surface conditions to create an intensified hydrological cycle, causing the vertical structure of the atmosphere to more closely approach the moist adiabatic condition.

3. Using CLIMAP SSTs in a simulation with the LMDH atmospheric model, Pinot et al. (this volume) simulated an increase in tropical free-air lapse rates that could account for $\approx 40 \%$ of the elevation effect estimated in this work. They also showed a spatial pattern in this effect similar to that shown here, with the strongest lapse rate increase in the Pacific region, and the weakest in the Neotropics.

4. A biological feedback on lapse rates might be produced by reduced vegetation cover at the LGM. "Tropical deforestation" experiments with GCMs typically show reduced latent-energy flux and convective activity due to surface energy-balance changes that accompany the prescribed reduction in vegetation cover (e.g. Dirmeyer and Shukla 1994; Polcher 1995; Zhang et al. 1996a, b; see also Potter et al. 1975 for results obtained with an early, zonally averaged climate model). Reduced latent-energy flux and convective activity lead in turn to cooling and drying of the middle troposphere, contributing to a regional steepening of free-air lapse rates. Such effects have yet to be investigated in simulations of the LGM climate.

5. The difference between terrestrial and free-air lapse rates may admit processes that could further amplify the impact of low-elevation temperature changes on high-mountain climates, relative to those processes currently included in atmospheric models. Ground temperature in high mountains is close to the temperature of overlying air, while at low elevations it can be several degrees higher. Terrestrial lapse rates are thus likely to be steeper than lapse rates derived from radiosonde observations, and steeper than those simulated by atmospheric models in which mountains are represented in a highly smoothed manner. Such effects may account for the 
large variations (both seasonal and spatial) which appear when lapse rates are estimated from climatological data, and which are considerably larger than the proposed difference in terrestrial lapse rates between LGM and present.

6. Further insight may come from observational and modelling studies of warmer than present climates. Pollen-based reconstructions for the mid-Holocene have shown that growing-season warming, relative to present, was amplified at higher elevations in the mountains of Europe (Huntley and Prentice 1988; Cheddadi et al. 1996) and eastern North America (Bartlein and Webb 1985). Cheddadi et al. (1996) inferred a lapse rate $\approx 1 \mathrm{~K} \mathrm{~km}^{-1}$ less steep than present in the generally warmer climate of $6000 \mathrm{y} \mathrm{BP}$ in Europe. A recent projection by Martin et al. (1997) of the effect of doubling $\mathrm{CO}_{2}$ on high mountain climates, using the CROCUS snow model, showed that the simulated upward retreat of snowline is considerably greater than would be expected based only on the sea-level temperature increase and the thermodynamic effect on free-air lapse rates.

We infer from these various lines of reasoning that there may well be a common mechanism linking observations of lowered SSTs at LGM to a weaker than present hydrological cycle, relative aridity on land as shown by PAM and $P-E$ reconstructions, land-surface cooling as shown by a variety of data sources, and increased tropical lapse rates as shown by the reconstructions of MTCO at low and high elevations. A more complete analysis of the problem must however await the compilation of ELA data that is now in progress, and a more quantitative analysis of the processes that takes into account the full range of constraints provided by palaeodata for the LGM.

\subsection{Concluding remarks}

A relatively clear picture has emerged from superficially heterogeneous data describing the state of the land surface around the LGM. In particular, apparent differences between different data sources (e.g. PAM versus $P-E$; geochemical estimates of MAT versus plant-based estimates of MTCO) largely disappear when the different spatial and elevational distributions of the data are taken into account. The single region where available MAT and MTCO anomaly estimates conflict (SE USA) is a subtropical region with a strongly seasonal climate today and where there are good reasons to expect that the seasonality was even greater at the LGM, allowing MTCO to be reduced more strongly than MAT. Our findings also have implications for the consistency of sea-surface temperature reconstructions. The terrestrial data provide support, albeit indirect, for the view that LGM sea-surface temperatures must have been lower than indicated by CLIMAP. At the same time, they set limits to the plausible magnitude of the average tropical cooling. Climate change between LGM and today is shown to be characterized by large-scale spatial patterns, which plausibly originated in changes to the oceanic and atmospheric circulation. A variety of physical processes, some already captured in atmospheric models, can potentially account for the (still robust) finding that tropical lapse rates at the LGM were steeper than present, while the strength of this phenomenon itself is shown to vary greatly in space. Although much remains to be done to complete the picture of the ice age Earth, the available data provide a rich source of qualitative and quantitative information that can constructively challenge our ability to predict the response modes of the climate system.

\section{Appendix}

A simple phenomenological model underlies the use of lapse rates in reconstructing temperature changes from elevational shifts in vegetation zones:

$T(z)=T(0)-s z$

$T^{*}(z)=T^{*}(0)-s^{*} z$

where $T(z)$ is the modern temperature at elevation $z$ above modern sea level, $s$ is a modern terrestrial lapse rate, and $T^{*}(z)$ and $s^{*}$ denote the corresponding palaeotemperature and lapse rate. From Eqs. (1) and (2),

$\Delta T(z)=\Delta T(0)-\varepsilon z$

where $\Delta T(z)=T^{*}(z)-T(z)$ is the temperature anomaly at elevation $z, \Delta T(0)=T^{*}(0)-T(0)$ is the temperature anomaly at modern sea level, and $\varepsilon=s^{*}-s$ is the change in lapse rate.

Palaeoecological data indicate the past vegetation near the elevation of the sampling site. We denote this elevation by $h^{*}$, representing the elevation where this type of vegetation was found in the past. Knowing the elevation $h$ at which similar vegetation is found today, we use Eqs. (1) and (2) to equate the temperatures $T(h)$ and $T^{*}\left(h^{*}\right)$ :

$T(0)-s h=T^{*}(0)-s^{*} h^{*}$

hence using relations (3) and (4),

$s\left(h^{*}-h\right)=\Delta T(0)-\varepsilon h^{*}$

By comparing Eqs. (3) and (5) we see that the standard estimator $s\left(h^{*}-h\right)$ (where $s$ is the modern lapse rate) is equivalent to the change in temperature at $h^{*}$, the elevation of the site. From Eq. (5), regression of this estimator against the site elevations will yield an intercept that estimates the temperature change at modern sea level, and a slope that estimates the change in lapse rate.

Acknowledgements This work was initiated in response to a request by the Palaeoclimate Modelling Intercomparison Project (PMIP) for an up-to-date multiproxy data set describing tropical terrestrial palaeoenvironments at the LGM. PMIP is sponsored by the IGBP and WCRP. Financial support was provided by the European Community (EV5V-CT95-0075), the Swedish Natural Science Research Council (G-AA/GU 09334-321), the Craafoord Foundation, and an NSF grant to TEMPO (Testing Earth system Models with Palaeoenvironmental Observations). The LGM data set has been archived in digital form at the National Geophysical Data Center 
(NGDC) at Boulder, Colorado, USA. We thank Bob Thompson and Roger Barry for discussions of lapse rates, and Dave Anderson for discussions about marine palaeotemperature records, while SPH and ICP were visiting scientists at the National Center for Atmospheric Research (NCAR) in Boulder, Colorado. NCAR is supported by the US National Science Foundation. We thank Tom Webb and Zhengyu Liu for helpful comments on the manuscript.

\section{References}

Anderson DM, Webb RS (1994) Ice-age tropics revisited. Nature $367: 23-24$

Anderson DM, Webb RS (1998) Tropical sea surface temperatures at the last glacial maximum reconstructed by removing the attenuation due to bioturbation. PAGES Open Science Conference Abstracts, 37

Andrews JN, Fontes JC, Aranyossy JF, Dodo A, Edmunds WM, Joseph A, Travi Y (1994) The evolution of alkaline groundwaters in the continental intercalaire aquifer of the Irhazer Plain, Niger Water Resources Res 30:45-61

Bakker J (1990) Tectonic and climatic controls on Late Quaternary sedimentary processes in a neotectonic intramontane basin (The Pitalito Basin, South Colombia) In: van der Hammen T (ed) The Quaternary of Colombia 16, Amsterdam, $169 \mathrm{pp}$

Bard E, Arnold M, Fairbanks RG, Zindler A (1990) Calibration of the ${ }^{14} \mathrm{C}$ timescale over the past 30,000 years using mass spectrometric U-Th ages from Barbados corals. Nature 345:405-410

Bard E, Rostek F, Sonzogni C (1997) Interhemispheric synchrony of the last deglaciation inferred from alkenone palaeothermometry. Nature 385:707-710

Bard E, Rostek F, Sonzogni C, Rahmstorf S, Ganopolski A (1998) Comparing temperatures of the glacial ocean quantified with the alkenone method and simulated by numerical models. PAGES Open Science Conference Abstracts, p20

Bar-Matthews M, Ayalon A, Kaufman A (1997) Late Quaternary Paleoclimate in the Eastern Mediterranean Region from stable isotope analysis of speleothems at Soreq Cave, Israel. Quat Res 47: $155-168$

Bartlein PJ, Webb T III (1985) Mean July temperature for eastern North America at 6,000 yr B.P.: regression equations for estimates based on fossil-pollen data. Syllogeus 55:301-342

Bartlein PJ, Whitlock C (1993) Paleoclimatic interpretation of the Elk Lake pollen record. In: Bradbury JP, Dean WE (Eds) Elk Lake Minnesota: evidence for rapid climate change in the northcentral United States. Geol Soc Am Spec Pap 276:275-293

Barnola JM, Raynaud D, Korotkevich YS, Lorius C (1987) Vostok ice core: a 160000 year record of atmospheric $\mathrm{CO}_{2}$. Nature 329: 408-414

Betts AK, Ridgway W (1992) Tropical boundary layer equilibrium in the last ice age. J Geophys Res 97:2529-2534

Bond G, Broecker WS, Johnsen SJ, McManus J, Labeyrie LD, Jouzel J, Bonani G (1993) Correlations between climate records from North Atlantic sediments and Greenland ice. Nature 365: 143-147

Broccoli AJ, Manabe S (1987) The influence of continental ice, atmospheric $\mathrm{CO}_{2}$, and land albedo on the climate of the last glacial maximum. Clim Dyn 1:87-99

Broccoli AJ, Marciniak EP (1996) Comparing simulated glacia climate and palaeodata: a reexamination. Paleoceanography $11: 3-14$

Broecker WS (1997) Mountain glaciers: recorders of atmospheric water vapor content? Glob Biogeochem Cycles 11:589-597

Broecker WS, Denton GH (1990) The role of ocean-atmosphere reorganizations in glacial cycles. Quat Sci Rev 9:305-342

Brook GA, Cowart JB, Brandt SA, Scott L (1997) Quaternary climatic change in southern and eastern Africa during the last $300 \mathrm{ka}$ : the evidence from caves in Somalia and the Transversal region of South Africa. Z Geomorph NF Suppl 108:15-48
Burney DA, James HF, Grady FV, Rafamantanantsoa JG Ramilisonina, Wright HT, Cowart JB (1997) Environmental change, extinction and human activity: evidence from caves in NW Madagascar. J Biogeogr 24:755-767

Bush ABG, Philander, SGH (1998) The role of ocean-atmosphere interactions in tropical cooling during the last glacial maximum. Science 279:1341-1344

Causse C, Conrad G, Fontes JC, Gasse F, Gibert E, Kassir A (1988) Le dernier "humide" pléistocène du Sahara nord-occidental daterait de 80-100000 ans. C R Acad Sci, Paris D 228:379-382

Chappellaz J, Barnola JM, Raynaud D, Korotkevich YS, Lorius C (1990) Ice core record of atmospheric methane over the past 160000 years. Nature 345:127-131

Cheddadi R, Yu G, Guiot J, Harrison SP, Prentice IC (1996) The climate 6000 years ago in Europe. Clim Dyn 13:1-9

Chen FH, Bloemendal J, Wang JM, Li JJ, Oldfield F (1997) Highresolution multi-proxy climate records from Chinese loess: evidence for rapid climatic changes over the last $75 \mathrm{ky}$. Palaeogeogr, Palaeoclimatol, Palaeoecol 130:323-335

COHMAP Members (1988) Climatic changes of the last 18,000 years: observations and model simulations. Science 241: 1043-1052

CLIMAP Project Members (1976) The surface of the ice-age Earth. Science 191:1131-1137

CLIMAP Project Members (1981) Seasonal reconstructions of the Earth's surface at the last Glacial Maximum. Geological Society of America Map Chart Series 36

Colinvaux PA, Liu KB, De Oliveira P, Bush MB, Miller MC Steinitz Kannan M (1996) Temperature depression in the lowland tropics in glacial times. Clim Change 32:19-33

Conrad G (1969) L'évolution continentale post-hercynienne du Sahara algérien (Saoura, Erg, Chech, Tanezrouft, Ahnet-Mouydir). Publication du Centre de Recherche sur les Zones arides CNRS sér Géol 10:527pp

Crowley TJ, Baum SK (1997) Effect of vegetation on an ice-age climate model simulation. J Geophys Res 120:16463-16480

Crowley TJ, Kim K-Y (1996) Comparison of proxy records of climate change and solar forcing. Geophys Res Lett 23:359-362

Dansgaard W, Johnsen SJ, Clausen HB, Dahl-Jensen D, Gundestrup NS, Hammer CU, Hvidberg CS, Steffensen JP, Sveinbjörnsdottir AE, Jouzel J, Bond G (1993) Evidence for general instability of past climate from a 250-kyr ice-core record. Nature $364: 218-220$

Davis MB (1991) Research questions posed by the paleoecological record of global change. In: Bradley RS (ed) Global changes of the past. UCAR/Office for Interdisciplinary Studies, Boulder, Colorado, pp. 385-395

Dearing JL, Foster IDL (1986) Lake sediments and palaeohydrological studies. In: Berglund BE (ed) Handbook of holocene palaeoecology and palaeohydrology. Wiley-Interscience, Chichester, pp 67-90

Diaz HF, Graham NE (1996) Recent changes in tropical freezing heights and the role of sea surface temperature. Nature 383 : 152-155

Dirmeyer PA, Shukla J (1994) Albedo as a modulator of climate response to tropical deforestation. J Geophys Res 99: 20863-20977

Fang J-Q (1991) Lake evolution during the past 30,000 years in China, and its implications for environmental changes. Quat Res $36: 37-60$

Fischer MJ, Gale SJ, Heijnis H, Drysdale, RN (1996) Low latitude speleothems and palaeoclimatic reconstruction. In: Lauritzen SE (ed) Climate change: the karst record. Karst Waters Inst Spec Publ $2: 62-64$

Foley JA, Levis S, Prentice IC, Pollard D, Thompson SL (1998) Coupling dynamic models of climate and vegetation. Global Change Biol 4:561-579

Fontes JC, Garnier JM (1979) Determination of the initial ${ }^{14} \mathrm{C}$ activity of the total dissolved carbon - A review of the existing models and a new approach. Water Resources Res 15:399-413 
Fontes JC, Andrews JN, Edmunds WM, Guerre A, Travi Y (1991) Paleorecharge by the Niger River (Mali) deduced from groundwater geochemistry. Water Resources Res 27:199-214

Fox AN, Bloom AL (1994) Snowline altitude and climate in the Peruvian Andes $\left(5-17^{\circ} \mathrm{S}\right)$ at present and during the latest Pleistocene glacial maximum. Journal of Geography (Japan) 103: $867-885$

Ganopolski A, Rahmstorf S, Petoukhov V, Claussen M (1998) Simulation of modern and glacial climates with a coupled global model of intermediate complexity. Nature 391:351-356

Gates L (1976) Modeling the Ice-age climate. Science 191: $1138-1144$

Grimm EC, Jacobson GL, Watts WA, Hansen BCS, Maasch KA (1993) A 50,000 years record of climate oscillations from Florida and its temporal correlation with the Heinrich events. Science $261: 198-200$

Guilderson TP, Fairbanks RG, Rubenstone JL (1994) Tropical temperature variations since 20,000 years ago: modulating interhemispheric climate change. Science 263:663-665

Guiot J (1990) Methodology of paleoclimatic reconstruction from pollen in France. Palaeogeogr Palaeoclimatol Palaeoecol $80: 49-69$

Guiot J (1991) Structural characteristics of proxy data and methods for quantitative climate reconstruction. Paläoklimaforschung $6: 271-284$

Guiot J, Harrision SP, Prentice IC (1993) Reconstruction of Holocene precipitation patterns in Europe using pollen and lake-level data. Quat Res 40:139-149

Guo ZT, Liu TS, Guiot J, Wu N, Lu H, Han J, Liu J, Gu Z (1996) High frequency pulses of east Asian monsoon climate in the last two glaciations: link with the North Atlantic. Clim Dyn $12: 701-709$

Harrison SP (1988) Lake-level records from Canada and the eastern USA. Lundqua Report (Lund University, Department of Quaternary Geology) 29, 9pp, 2 appendices

Harrison SP (1989) Lake-level records from Australia and Papua New Guinea. UNGI Rapport 72:1-42. (Uppsala University, Department of Physical Geography)

Harrison SP, Digerfeldt G (1993) European lakes as palaeohydrological and palaeoclimatic indicators. Quat Sci Rev 12:233-248

Hartmann DL (1994) Global physical climatology. Academic Press, San Diego, $411 \mathrm{pp}$

Heaton THE, Vogel JC (1981) "Excess air" in groundwater. J Hydrol 50: 201-216

Helmens KF, Kuhry P, Rutter NW, Van der Borg K, De Jong AFM (1996) Warming at 18,000 years B.P. in the tropical Andes. Quat Res 45:289-299

Henderson-Sellers B (1984) Engineering limnology. Pitman, London, $356 \mathrm{pp}$

Hendy CH (1971) The isotropic geochemistry of speleothems-I. The calculation of the effects of different modes of formation on the isotopic composition of speleothems and their applicability as palaeoclimate indicators. Geochim Cosmochim Acta 35: 801-824

Herzberg O, Mazer E (1979) Hydrological applications of noble gases and temperature measurements in underground water systems: examples from Israel. J Hydrol 41:217-231

Hewitt CD, Mitchell JFB (1998) A fully coupled GCM simulation of the climate of the mid-Holocene. Geophy Res Lett 25:361-364

Holmgren K, Karlén W, Shaw P (1995) Paleoclimatic significance of variations in stable isotopic composition and petrology of a late Pleistocene stalagmite from Botswana. Quat Res 43:320-328

Hostetler SW, Clark PU (1997) Climatic controls of western U.S. glaciers at the last glacial maximum. Quat Sci Rev 16: 505-511

Houghton JT, Meira Filho LG, Callander BA, Harris N, Kattenberg A, Maskell K (eds) (1996) Climate change 1995: the science of climate change. Cambridge University Press, Cambridge, UK

Huntley B, Prentice IC (1988) July temperatures in Europe from pollen data 6000 years before present. Science 241:687-690
Jackson ST, Overpeck JT, Webb T III, Keattch SE, Anderson KH (1997) Mapped plant-macrofossil and pollen records of Late Quaternary vegetation changes in eastern North America. Quat Sci Rev 16:1-70

Johnsen SJ, Clausen HB, Dansgaard W, Fuhrer K, Gundestrup N, Hammer CU, Iversen P, Jouzel J, Stauffer B, Steffensen JP (1992) Irregular glacial interstadials recorded in a new Greenland ice core. Nature 359:311-313

Jolly D, Haxeltine A (1997) Effect of low glacial atmospheric $\mathrm{CO}_{2}$ on tropical African montane vegetation. Science 276:786-787

Jolly D, Harrison SP, Damnati B, Bonnefille R (1998a) Simulated climate and biomes of Africa during the Late Quaternary: comparison with pollen and lake status data. Quat Sci Rev 17:629-657

Jolly D, Prentice IC, Bonnefille R, Ballouche A, Bengo M, Brénac P, Buchet G, Burney D, Cazet JP, Cheddad R, Edorh T, Elenga H, Elmoutaki S, Guiot J, Laarif F, Lamb H, Lézine AM, Maley J, Mbenza M, Peyron O, Reille M, Reynaud-Farrera I, Riollet G, Ritchie JC, Roche E, Scott L, Ssemmanda I, Straka H, Umer M, Van Campo E, Vilimumbalo S, Vincens A, Waller M (1998b) Biome reconstruction from pollen and plant macrofossil data for Africa and Arabian peninsula at 0 and 6000 years. J of Biogeogr 25: 1007-1027

Joussaume S, Taylor KE (1995) Status of the Paleoclimate Modeling Intercomparison Project (PMIP). In: Proc First Int AMIP Sci Conf (Monterey, California, USA, 15-19 May 1995). WCRP Report $92: 425-430$

Joussaume S, Taylor KE, Braconnot P, Mitchell J, Kutzbach J, Harrison SP, Prentice IC, Broccoli AJ, Abe-Ouchi A, Bartlein PJ, Bonfils C, Dong B, Guiot J, Herterich K, Hewitt C, Jolly D, Kim JW, Kislov A, Kitoh A, Loutre MF, Masson V, McAvaney B, McFarlane N, de Noblet N, Peltier WR, Peterschmitt JY, Pollard D, Rind D, Royer JF, Schlesinger ME, Syktus J, Thompson S, Valdes P, Vettoretti G, Webb RS, Wyputta U (1999) Monsoon changes for $6000 \mathrm{y}$ ago: results of 18 simulations from the Paleoclimate Modeling Intercomparison Project (PMIP). Geophys Res Lett (in press)

Kattenberg A, Giorgi F, Grassl H, Meehl GA, Mitchell JFB, Stouffer RJ, Tokioka T, Weaver AJ, Wigley TML, 1996. Climate models - projections of future climate. In Houghton, JT, Meira Filho LG, Callander BA, Harris N, Kattenberg A, Maskell K (eds) Climate change 1995: the science of climate change. Cambridge University Press, Cambridge, pp. 285-357

Kutzbach JE, Guetter PJ (1986) The influence of changing orbital parameters and surface boundary conditions on climate simulations for the past 18000 years. J Atmos Sci $43: 1726-1759$

Kutzbach JE, Liu Z (1997) Response of the African monsoon to orbital forcing and ocean feedbacks in the middle Holocene Science 278:440-443

Kutzbach JE, Guetter PJ, Behling P, Selin R (1993) Simulated climatic changes: results of the COHMAP climate-model experiments. In: HE Wright Jr, JE Kutzbach, T Webb III. WF Ruddiman, FA Street-Perrott, PJ Bartlein (eds) Global climates since the Last Glacial Maximum, University of Minnesota Press, Minneapolis, pp 24-93

Kutzbach JE, Gallimore R, Harrison SP, Behling P, Selin R, Laarif F (1998) Climate and biome simulations for the past 21,000 years. Quat Sci Rev 17:473-506

Lauritzen S-E (1993) Natural environmental change in karst: the Quaternary record. Catena Suppl 25:133-146

Lauritzen S-E (ed) (1996) Climate change: the karst record. Karst Waters Inst Spec Publ 2

Ledru M-P, Bertaux J, Sifeddine A, Suguio K (1998) Absence of last glacial maximum records in tropical lowland forests. Quat Res $49: 233-237$

Leemans R, Cramer W (1991) The IIASA climate database for mean monthly values of temperature, precipitation and cloudiness on a global terrestrial grid. RR-91-18. International Institute for Applied Systems Analysis (IIASA), Laxenburg, Austria 
Leuenberger M, Siegenthaler U (1992) Ice age atmospheric concentration of nitrous oxide from an Antarctic ice core. Nature $360: 449-451$

Li W-X, Lundberg J, Dickin AP, Ford DC, Schwarcz HP, McNutt R, Williams D (1989) High-precision mass-spectrometric uranium-series dating of cave deposits and implications for palaeoclimate studies. Nature 339:534-536

Lorius C, Oeschger H (1994) Palaeo-perspective: reducing uncertainties in global change? Ambio 23:30-36

Manabe S, Hahn DG (1977) Simulation of the tropical climate of an ice age. J Geophys Res 82:3889-3911

Manabe S, Broccoli AJ (1985a) The influence of continental ice sheets on the climate of an ice age. J Geophys Res 90 $2167-2190$

Manabe S, Broccoli AJ (1985b) A comparison of climate model sensitivity with data from the last glacial maximum $\mathbf{J}$ Atmos Sci $42: 2643-2651$

Martin E, Timbal B, Brun E (1997) Downscaling of general circulation model outputs: simulation of the snow climatology of the French Alps and sensitivity to climate change. Clim Dyn $13: 45-56$

Mason IM, Guzkowska MAJ, Rapley CG, Street-Perrott FA (1994) The response of lake levels and areas to climatic change. Clim Change 27:161-197

Mazor E (1972) Paleotemperatures and other hydrological parameters deduced from noble gases dissolved in groundwaters; Jordan Rift Valley Israel. Geochim Cosmochim Acta 36:1321-1336

Oerlemans J (1986) Glaciers as indicators of a carbon dioxide warming. Nature 320:607-609

Ono Y (1988) Last glacial snowline altitude and paleoclimate of the eastern Asia. Quat Res (Japan) 26:271-280

Ono Y, Naruse T (1997) Snowline elevation and eolian dust flux in the Japanese Islands during isotope stages 2 and 4. Quat Int $37: 45-54$

Patrick A, Thunell RC (1997) Tropical Pacific sea surface temperature and upper water column thermal structure during the last glacial maximum. Paleoceanography 12:649-657

Peltier WR (1994) Ice age paleotopography. Science 265: 195-201

Peterson GM, Webb T III, Kutzbach JE, van der Hammen T, Wijmmstra T, Street FA (1979) The continental record of environmental conditions at 18,000 years B.P.: an initial evaluation. Quat Res 12:47-82

Peyron O, Guiot J, Cheddadi R, Tarasov P, Reille M, de Beaulieu JL, Bottema S, Andrieu V (1998) Climate reconstruction in Europe for 18,000 years B.P. from pollen data. Quat Res 49:183-196

Phillips FM, Tansey MK, Peeters LA (1989) An isotopic investigation of groundwater in the central San Juan Basin, New Mexico: Carbon 14 dating as a basis for numerical flow modeling. Water Resources Res 25:2259-2273

Pinot S, Ramstein G, Harrison SP, Prentice IC, Guiot J, Joussaume S, Stute M, PMIP participating groups (this volume) Tropical palaeoclimates at the Last Glacial Maximum: comparison of Palaeoclimate Modelling Intercomparison Project (PMIP) simulations and palaeodata. Clim Dyn 15:857-874

Polcher J (1995) Sensitivity of tropical convection to land surface processes. J Atmos Sci 52:3143-3161

Porter SC, An Z (1995) Correlation between climate events in the North Atlantic and China during the last glaciation. Nature 375:305-308

Potter GL, Ellsaesser HW, McCracken MC, Luther FM (1975) Possible climatic impact of tropical deforestation. Nature 258:697-698

Prell WL, Trend MA, Martin AH (1996) Modern analog technique (MAT estimates of sea surface temperature (SST) at the last glacial maximum (LGM): a comparison to CLIMAP (1981) SSTs. Abstracts with Programs, Geol Soc Am 28:272

Prentice IC (1988) Records of vegetation in time and space: the principles of pollen analysis. In: B. Huntley, T. Webb III (eds) Vegetation history, Kluwer Academic Publishers, Dordrecht, pp 17-42
Prentice IC, Webb III T (1998) BIOME 6000: reconstructing global mid-Holocene vegetation patterns from palaeoecological records. J Biogeogr 25:997-1005

Prentice IC, Bartlein PJ, Webb T III (1991) Vegetation and climate changes in eastern North America since the last glacial maximum. Ecology 72:2038-2056

Prentice IC, Guiot J, Harrison SP (1992a) Mediterranean vegetation, lake levels and palaeoclimate at the Last Glacial Maximum. Nature 360:658-670

Prentice IC, Cramer W, Harrison SP, Leemans R, Monserud RA, Solomon AM (1992b) A global biome model based on plant physiology and dominance, soil properties and climate. J Biogeogr 19: 117-134

Prentice IC, Guiot J, Huntley B, Jolly D, Cheddadi R (1996) Reconstructing biomes from palaeoecological data: a general method and its application to European pollen data at 0 and $6 \mathrm{ka}$. Clim Dyn 12:185-194

Rahmstorff S (1994) Rapid climate transitions in a coupled oceanatmosphere model. Nature 372:82-85

Roberts N, Wright Jr HE (1993) Vegetational, Lake-Level, and Climatic History of the Near East and Southwest Asia. In: Wright HE, Kutzbach JE, Webb III T, Ruddiman WF, StreetPerrott-FA, Bartlein PJ (eds) Global Climates since the Last Glacial Maximum. University of Minnesota Press, MinneapolisLondon, 194-220

Rodbell DT (1992) Late Pleistocene equilibrium-line reconstructions in the northern Peruvian Andes. Boreas 21:43-52

Rind D (1990) Puzzles from the tropics. Nature 346:317-318

Rind D, Peteet D (1985) Terrestrial conditions at the last glacial maximum and CLIMAP sea-surface temperature estimates: are they consistent? Quat Res 24:1-22

Rudolf J, Rath HK, Sonntag C (1984) Noble gases and stable isotopes in ${ }^{14} \mathrm{C}$-dated paleowaters from central Europe and the Sahara. In: Isotope hydrology, IAEA, Vienna, pp 467-477

Sarmiento JL, Le Quéré C (1996) Oceanic carbon dioxide uptake in a model of century-scale global warming. Science 274: $1346-1350$

Sarmiento JL, Hughes TMC, Stouffer RJ, Manabe S (1998) Simulated response of the ocean carbon cycle to anthropogenic climate warming. Nature $393: 245-249$

Schubert C, Clapperton CM (1990) Quaternary glaciations in the northern Andes (Venezuela, Colombia, Ecuador) Quat Sci Rev 9:123-135

Schwarcz HP (1986) Grochronology and isotopic geochemistry of speleothems. In: Fritz P, Fontes JCh (eds) Handbook of environmental isotope geochemistry 2: Elsevier, Amsterdam, 271-303 pp

Sharma MC, Owen LA (1996) Quaternary glacial history of NW Garhwal, Central Himalayas. Quat Sci Rev 15:335-365

Shaw PA, Cooke HJ (1986) Geomorphic evidence for the late Quaternary palaeoclimates of the Middle Kalahari of northern Botswana. Catena 13:349-359

Sikes EL, Keigwin L (1994) Equatorial Atlantic sea surface temperatures for the last $30 \mathrm{kyr}$ : a comparison of $\mathrm{U}_{37}^{\mathrm{k}^{\prime}}, \delta^{18} \mathrm{O}$ and foraminiferal assemblage temperature estimates. Paleoceanography $9: 31-45$

Stocker T, Schmitter A (1997) Influence of $\mathrm{CO}_{2}$ emission rates on the stability of the thermohaline circulation. Nature 388, 862-865

Street-Perrott FA (1994) Palaeo-perspectives: changes in terrestrial ecosystems. Ambio 23:37-43

Street-Perrott FA, Harrison SP (1985) Lake levels and climate reconstruction. In: Hecht $\mathrm{AD}$ (ed) Paleoclimate analysis and modeling. John Wiley, New York, pp 291-340

Street-Perrott FA, Marchand DS, Roberts N, Harrison SP (1989) Global lake-level variations from 18000 to 0 years ago: a palaeoclimatic analysis. US DOE/ER/60304-H1 TR046. US. Department of Energy, Technical Report

Street-Perrott FA, Yongsong Huang, Perrott RA, Eglinton G Barker P, Ben Khelifa L, Harkness DD, Olago DO (1997) Impact of lower atmospheric carbon dioxide on tropical mountain ecosystems. Science $278: 1422-1426$ 
Stute M, Schlosser P (1993) Principles and applications of the noble gas paleothermometer. In: Swart PK, Lohmann KC, McKenzie J, Savin S (eds) Climate change in continental isotopic records. Geophy Monogr 78:89-100

Stute M, Schlosser P, Clark JF, Broecker WS (1992) Paleotemperatures in the Southwestern United States derived from noble gas measurements in groundwater. Science 256:1000-1003

Stute M, Forster M, Frischkorn H, Serejo, Clark P, Broecker WS, Bonani (1995) Cooling of tropical Brazil $\left(5{ }^{\circ} \mathrm{C}\right)$ during the Last Glacial Maximum. Science 269:379-383

Sykes MT, Prentice IC, Cramer W (1996) A bioclimatic model for the potential distributions of north European tree species under present and future climates. J Biogeogr 23:203-233

Szestay K (1974) Water balance and water level fluctuations of lakes. Hydrol Sci Bull 19:73-84

Talma AS, Vogel JC (1992) Late Quaternary paleotemperatures derived from a speleothem from Cango Caves, Cape Province, South Africa. Quat Res 37:203-213

Tarasov PE, Pushenko MYa, Harrison SP, Saarse L, Andreev AA, Aleshinskaya ZV Davydova NN, Dorofeyuk NI, Efremov YuV, Elina GA, Elovicheva YaK, Filimonova LV, Gunova VS, Khomutova VI, Kvavadze EV, Neustreuva IYu, Pisareva VV, Sevastyanov DV, Shelekhova TS, Subetto DA, Uspenskaya ON, Zernitskaya VP (1996) Lake status records from the former Soviet Union and Mongolia: documentation of the Second Version of the Database. NOAA Paleoclimatology Publications Series Report 5, 224pp

Thompson L, Mosley-Thompson E, Davis ME, Lin PN, Hernderson KA, Cole-Dai J, Bolzan JF, Liu KB (1995) Late glacial stage and Holocene Tropical ice core records from Huascaran, Peru. Science 269:46-50

Thouret J-C, Van der Hammen T, Salomons B, Juvigné E (1996) Palaeoenvironmental changes and glacia stades of the last 50,000 years in the Cordillera Central, Colombia. Quat Res $46: 1-18$

Van der Hammen T (1974) The Quaternary climatic changes of northern South America. Ann New York Acad Sci 95:676-683

Van der Hammen T (1991) Paleoecological background: Neotropics. Clim Change 19:39-48

Van der Hammen T, Absy ML (1994) Amazonia during the last glacial. Palaeogeogr Palaeoclimatol Palaeoecol 109:247-261

Van Devender TR, Thompson RS, Betancourt JL (1987) Vegetation history of the deserts of southwestern North America; the nature and timing of the Late Wisconsin-Holocene transition. In: Ruddiman WF, Wright HE Jr (eds) North America and adjacent oceans during the last deglaciations. The Geology of North America vol K-3: pp 323-352

Walker B, Steffen W (1997) The terrestrial biosphere and global change: implications for natural and managed ecosystems. A synthesis of GCTE and related research. IGBP Science 1, IGBP, Stockholm, $32 \mathrm{pp}$

Walker DA, Flenley JR (1979) Late Quaternary vegetational history of the Enga district of upland Papua New Guinea. Philos Trans R Soc B 286:265-344

Watts WA, Allen JRM, Huntley B (1996) Vegetation history and palaeoclimate of the Last Glacial Period at Lago Grande di Monticchio, southern Italy. Quat Sci Rev 15:113-132

Weaver AJ, Eby M, Fanning AF, Wiebe EC (1998) Simulated influence of carbon dioxide, orbital forcing and ice sheets on the climate of the Last Glacial Maximum. Natura 394:847-853

Webb RS, Rind DH, Lehman SJ, Healy RJ, Sigman D (1997) Influence of ocean heat transport on the climate of the Last Glacial Maximum. Nature 385:695-699

Webb III T (1985) A global paleoclimate data base for $6000 \mathrm{yr}$ B.P. DOE/EV/10097-6, US Department of Energy, Washington, $155 \mathrm{pp}$

Webb T III, Bartlein PJ, Harrison SP, Anderson KH (1993) Vegetation, lake-levels, and climate in eastern North America since 12000 yr B.P. In: Wright Jr HE, Kutzbach JE, Webb T III, Ruddiman WF, Street-Perrott FA, Bartlein PJ (eds) Global climates since the Last Glacial Maximum, University of Minnesota Press, Minneapolis, pp 415-467

Webster PL, Streten NA (1978) Late Quaternary ice age climate of tropical Australasia: interpretations and reconstructions. Quat Res 10:279-309

Williams J, Barry RG, Washington WM (1974) Simulation of the atmospheric circulation using the NCAR global circulation model with Ice Age boundary conditions. J Appl Meteorol $13: 305-317$

Woodward FI (1987) Climate and plant distribution. Cambridge University Press, Cambridge, UK

Wright Jr HE, Kutzbach JE, Webb T III, Ruddiman WF, StreetPerrott FA, Bartlein PJ (eds.) (1993) Global climates since the Last Glacial Maximum. University of Minnesota Press, Minneapolis, $569 \mathrm{pp}$

Yu G, Harrison SP (1995) Lake status records from Europe: Data base documentation. NOAA Paleoclimatology Publications Series Report 3:451pp

Yu G, Prentice IC, Harrison SP, Sun X (1998) Biome reconstructions for China at 0 and 6 ka. J Biogeogr 25:1055-1069

Zielinski GA, McCoy WD (1987) Paleoclimatic implications of the relationship between modern snowpack and late Pleistocene equilibrium-line altitudes in the mountains of the Great Basin, western USA Arctic Alpine Res 19:127-134

Zhang H, Henderson-Sellers A, McGuffie K (1996a) Impacts of tropical deforestation. Part I: Process analysis of local climatic change. J Clim 9:1497-1517

Zhang H, Henderson-Sellers A, McGuffie K (1996b) Impacts of tropical deforestation. Part II: the role of large-scale dynamics. J Clim 9:2498-2521

\section{Data base references}

Absy ML, Cleef A, Fournier M, Martin L, Servant M, Siffeddine A Ferreira da Silva M, Soubiés F, Sugino F, Sugino K, Turcq B, Van der Hammen T (1991) Mise en évidence de quatre phases d'ouverture de la forêt dense dans le sud-est de l'Amazonie au cours des 60000 dernières années. Première comparaison avec d'autres régions tropicales. C R Acad Sci, Paris 312 II : $673-678$

Argolla J, Mourguiart P (1995) Paleohidrología de los últimos 25000 años en los Andes Bolivianos. Bull Insti FR Étud Andines $24: 551-562$

Barberi M (1994) Paleovegetacão e paleoclima no Quaternário tardio da vereda de Águas Emendadas, DF. Dissertation, University of Brasilia

Bar-Matthews M, Ayalon A, Kaufman A (1997) Late Quaternary paleoclimate in the Eastern Mediterranean region from stable isotope analysis of speleothems at Soreq Cave, Israel. Quat Res 47: $155-168$

Behling H (1997) Late Quaternary vegetation, climate and fire history from the tropical mountain region of Morro de Itapeva, SE Brazil. Palaeogeogr Palaeoclimatol, Palaeoecol 129: 407-422

Behling H, Lichte M (1997) Evidence of dry and cold climatic conditions at glacial times in tropical southeastern Brazil. Quat Res 48:348-358

Behling H, Lichte M, Miklos AW (1998) Evidence of a forest free landscape under dry and cold climate conditions during the last glacial maximum in the Botucatú region (São Paulo State), Southeastern Brazil. Quat S America Antarct Penin 6:99-110

Behling (1996) First report on new evidence for the occurrence of Padocarpus and possible human presence at the mouth of the Amazon during the Late-glacial. Veget Hist Archaeobot $5: 241-246$

Bonnefille R (1987) Evolution forestière et climatique au Burundi durant les quarant les quarante dermiers milliers d'années. C R Acad Sci, Paris 305 II : 1021-1026 
Bonnefille R, Riollet G (1988) The Kashiru pollen sequence (Burundi): palaeoclimatic implications for the last $40000 \mathrm{yrs} \mathrm{BP}$ in Tropical Africa. Quat Res 30:19-35

Bonnefille R, Chalié F, Guiot J, Vincens A (1992) Quantitative estimates of full glacial temperatures in Equatorial Africa from palynological data. Clim Dyn 6:251-257

Bonnefille R, Riollet G, Buchet G, Icolo M, Lafont R, Arnold M, Jolly D (1995) Glacial/Interglacial record from intertropical Africa, high resolution pollen and carbon data at Rusaka, Burundi. Quat Sci Rev 14:917-936

Bonnefille R, Roeland JC, Guiot J (1990) Temperature and rainfall estimates for the past 40000 years in equatorial Africa. Nature 346:347-349

Bradbury JP (1989) Late Quaternary lacustrine palaeoenvironments in the Cuenca de Mexico. Quat Sci Rev 8:75-100

Brenac P (1988) Evolution de la végétation et du climat dans l'Quest-cameroun entre 25000 et 11000 ans BP. Actes 10e Symposium APLF, Inst Fr Pondichery. Trav Sect Sci Tech 25:91-103

Brook GA, Cowart JB, Brandt SA, Scott L (1997) Quaternary climatic change in southern and eastern Africa during the last $300 \mathrm{ka}$ : the evidence from caves in Somalia and the Transvaal region of South Africa. Z Geomorphol NF Suppl 108:15-48

Brown RB (1985) A summary of late-Quaternary pollen record from Mexico west of the Isthmus of Tehuantepec. In: Bryant VM and Holloway RG (eds), Pollen records of late-Quaternary North American sediments A.A.S.P. Foundation USA, pp 71-94

Burney DA, James HF, Grady FV, Rafamantanantsoa J-G, Ramilisonina, Wright HT, Cowart JB (1997) Environmenta change, extinction and human activity: evidence from caves in NW Madagascar. J Biogeogr 24, 755-767

Bush M, Colinvaux PA (1990) A pollen record of a complete glacial cycle from lowland Panama. J Veget Sci 1, 105-118

Bush MB, Colinvaux P, Wiemann M, Piperno D, Liu K-B (1990) Late Pleistocene temperature depression and vegetation change in Ecuadorian Amazonia. Quat Res 34, 330-345

Cao QY, Zhu RY, Wang FB (1993) Pollen analysis and changes in environments. In: Quaternary sediments and engineering geological conditions, Nanjing University Press, Nanjing, pp 61-66 (in Chinese)

Chalié F (1995) Paléoclimats du bassin Tanganyika Sud au cours des 25 dermiers mille ans: reconstitution quantitative par le traitement statistique de données polliniques. C R Acad Sci, Paris 320 IIa: 205-210

Chen JR, Huang CY, Lin MF, Jin QH, Han JX (1990) Tianyang Maar of Quaternary Geology in Guangdong Province. Geology Press, Beijing: $197 \mathrm{p}+50$ diagrams (in Chinese)

Clark JD, Van Zinderen Bakker EM (1964) Prehistoric culture and Pleistocene vegetation at the Kalambo Falls, Northern Rhodesia. Nature 201:971-975

Clark JF, Stute M, Schlosser P, Drenkard S, Bonani G (1997) An isotope study of the Floridan aquifer in southeastern Georgia: implications for groundwater flow and palaeoclimate. Water Resources Res 33:281-290

Coetzee JA (1967) Pollen analytical studies in East and Southern Africa. Palaeoecol Afr 3:1-46

Colinvaux PA (1972) Climate and te Galapagos Islands. Nature $240: 17-20$

Colinvaux PA (1996) Quaternary environmental history and forest diversity in the neotropics. In: J Jackson, A Coates (eds) Environmental and Biological Change in Neogene and Quaternary Tropical America. Chicago University, Chicago, Illinois, pp 359-405

Colinvaux PA, Liu KB, De Oliveira P, Bush MB, Miller MC, Steinitz Kannan M (1996) Temperature depression in the lowland tropics in glacial times. Clim Change 32:19-33

Colinvaux PA, Bush MB, Steinitz-Kannan M, Miller MC (1997) Glacial and postglacial pollen records from the Equadorian Andes and Amazon, Quat Res 48, 69-78

De Oliveira PE (1992) A Palynological Record of Late Quaternary Vegetation and Climate Change in Southeastern Brazil. PhD Thesis, Ohio State University, Columbus
De Oliveira PE (1996) Glacial cooling and forest disequilibrium in western Amazonia. Anal Acad Brasil Ciéncias, 68 Suppl: 129-138

Delcourt PA (1980) Goshen springs: Late Quaternary vegetation record for Southern Alabana. Ecology 61:371-386

Dodson JR, Wright VS (1989) Humid to arid to subhumid vegetation shift on Pilliga sandstone, Ulungra Springs, New South Wales. Quat Res 32:182-192

Edmunds WM, Fellman E, Baba Goni I, McNeill G, Harkness DD (1998) Groundwater, paleoclimate and paleorecharge in the SW Chad Basin, Borno State, Nigeria. In: Isotope techniques in the study of environmental change, International Atomic Energy Agency (IAEA), Vienna

Elenga H, Schwartz D, Vincens A (1994) Pollen evidence of Late Quaternary vegetation and inferred climate changes in Congo. Palaeogeogr Palaeoclimato Palaeoecol 109:345-356

Ferraz-Vicentini KR, Salgado-Labouriau ML (1996) Palynological analysis of a palm swamp in Central Brazil. J S Am Earth Sci 93(4) : 207-219

Fischer MJ, Gale SJ, Heijnis H, Drysdale RN (1996) Low latitude speleothems and palaeoclimatic reconstruction. In: S-E Lauritzen (ed) Climate change: the karst record. Karst Waters Inst Spec Publ 2: 62-64

Flenley JR (1984) Late Quaternary changes of vegetation and climate in the Malesia Mountains. Erdwissenchaft Forsch XVIII : 261-267

Flenley JR, King SM (1984) Late Quaternary pollen records from Easter Island. Nature 307:47-50

Flenley JR, King ASM, Jackson J, Chew C, Teller JT, Prentice E (1991) The Late Quaternary vegetational and climatic history of Easter Island. J Quat Sci 6:85-115

Gasse F, Cortijo E, Disnar J-R, Ferry L, Gibert E, Kissel C, Laggoun-Defarge F, Lallier-Vergès E, Miskovsky J-C, Ratsimbazafy B, Ranaiva F, Robison L, Tucholka P, Saos J-L, Stiffedine A, Taieb M, Van Campo E, Williamson D (1994) A 36 ka environmental record in the southern tropics: Lake Tritrivakley (Madagascar). C R Acad Sci, Paris 318 II : 1513-1519

Giresse P, Maley J, Kelts K (1991) Sedimentation and paleoenvironment in crater lake Barombi-Mbo, Cameroon, during the last 25,000 years. Sediment Geol 71:151-175

Gonzalez-Quintero L, Fuentes Mata M (1980) El Holoceno de la porcion central de la Cuenca de Mexico. Mem Inst N Antrop Hist III Coloquio sobre Paleobotanica y Palinología (Mexico City, 1977) $86: 133-158$

Graf K (1992) Pollendiagramme aus den Anden: Eine Synthese zur Klimageschichte und Vegetationsentwicklung seit der letzten Eiszeit. Phys Geogr 34, University of Zürich, Switzerland

Grimm EC, Jacobson Jr GL, Watts WA, Hansen BCS, Maasch KA (1993) A 50,000-year record of climate oscillations from Florida and its temporal correlation with the Heinrich Events. Science $261: 198-200$

Gupta HP, Prasad K (1985) The vegetational development during 30,000 years BP at Colgrain, Ootacamund, Nilgiris, South India. J Palynol 21:174-187

Harberle S (1994) Anthropogenic indicators in pollen diagrams: problems and prospects for late Quaternary palynology in New Guinea. In: J Hather (ed) Tropical archaebotany Routledge, London, pp 172-201

Harberle S (1998) Late Quaternary vegetation change in the Tari Basin, Papua New Guinea. Palaeogeogr Palaeoclimatol Palaeoecol 137: 1-24

Hamilton AC (1982) Environmental history of East Africa. A study of the Quaternary. Academic Press, London, 328 p

Han HY, Yu JB (1988) Pollen analysis and palaeoenvironment study of Late Pleistocene in Dahanbar, Guizhou Province. Acta Bota Sinica 30:76-84

Hansen BCS, Wright Jr HE, Bradbury JP (1984) Pollen studies in the Junin area, central Peruvian Andes. Bull Geol Soc Am $95: 1454-1465$

Harrison SP (1988) Lake-level records from Canada and the eastern U.S.A. Lundqua Report (Lund University, Department of Quaternary Geology) 29, 9pp, 2 appendices 
Harrison SP (1989) Lake-level records from Australia and Papua New Guinea. UNGI Rapport 72:1-42, Uppasala University, Department of Physical Geography

Heaton THE, Talma AS, Vogel JC (1986) Dissolved gas paleotemperatures and $18 \mathrm{O}$ variations derived from groundwater near Uitenhage, South Africa. Quat Res 25:79-88

Helmens KF, Kuhry P (1986) Middle and Late Quaternary vegetational and climatic history of the Paramo de Agua Blanca (Eastern Cordillera, Colombia). Palaeogeogr Palaeoclimatol Palaeoecol 56:291-335

Helmens KF, Kuhry P (1995) Glacier fluctuations and vegetation change associated with Late Quaternary climatic oscillations in the Andes near Bogotá (Colombia). Quat S Am Antarct Penin 9: $117-140$

Helmens KF, Kuhry P, Rutter NW, Van der Borg K, de Jong AFM (1996) Warming at $18000 \mathrm{yr}$ B.P. in the tropical Andes. Quat Res $45: 289-299$

Holmgren K, Karlen W, Shaw P (1995) Paleoclimatic significance of variations in stable isotropic composition and petrology of a late Pleistocene stalagmite from Botswana. Qua Res 43:320-328

Hooghiemstra H (1984) Vegetational and climatic history of the high plain of Bogota, Colombia: a continuous record of the last 3,5 million years. Dissertaciones Botanicae 79, J Cramer, Vaduz, $368 \mathrm{pp}$

Hooghiemstra H, Cleef AM. Noldus GW, Kappelle M (1992) Upper Quaternary vegetation dynamics and paleoclimatology of the La Chonta bog area, Cordillera de Talamanca, Costa Rica. J Quat Sci 7:205-225

Hope G, Tulip J (1994) A long vegetation history from lowland Irian Jaya, Indonesia. Palaeogeogr, Palaeoclimatol Palaeoecol $109: 385-398$

Hope GS (1976) The vegetational history of Mt Wilhelm, Papua, New Guinea. J Ecol 64:627-661

Hope GS (1982) Pollen from archaeological sites: a comparison of swamp and open archaeological site pollen spectra at Kosipe Mission, Papua New Guinea. In: W Ambrose, P Duerden (eds) Archaeometry: an Australian perspective. Australian Nation

Hope GS (1983) The vegetational changes of the last 20,000 years at Telefomin, Papua New Guinea. Singapore J Trop Geogr 4: 25-33

Hope GS (1996a) History of Nothofagus in New Caledonia. In: TT Veblen et al. (eds) The ecology and biogeography of Nothofagus Forest. pp 257-270

Hope GS (1996b) Quaternary change and historical biogeography of Pacific Islands. In: A Keast, SE Miller (eds) The origin and evolution of Pacific islands biotas, New Guinea to Eastern Polynesia: patterns and process. SPB Publishing, pp 165-190

Hope GS, Gillieson D (1990) Palaeoenvironments. In: B Craig, D Hyndman (eds) Children of Afek, University of Chicago

Huang ZG (1982) Pollen records and climate changes. In: Formation and evolution of Zhujiang Delta. Guangzhou Universal Science Press, Guangzhou, pp 118-146 (in Chinese)

Igarashi Y, Yoshida M, Tabata H (1988) History of vegetation and climate in the Kathmandu Valley. Proc Indian Nat Acad $54: 550-563$

Islebe GA, Hooghiemstra H (1997) Vegetation and climate history of montane Costa Rica since the Last Glacial. Quat Sci Rev $16: 589-604$

Jackson ST, Givens CR (1994) Late Wisconsinan Vegetation and Environment of the Tunica Hills Region, Louisiana/Mississippi. Quat Res 41:316-325

Jolly D, Harrison SP, Damnati B, Bonnefille R (1998a) Simulated climate and biomes of Africa during the Late Quaternary: comparison with pollen and lake status data. Quat Sci Rev $17: 629-657$

Kershaw AP (1976) A Late Pleistocene and Holocene pollen diagram from Lynch's Crater, North eastern Queensland, Australia. New Phytol 77:469-498

Kershaw AP (1994) Pleistocene vegetation of the humid tropics of northeastern Queensland, Australia. Palaeogeogr Palaeoclimatol Palaeoecol 109:399-412
Kershaw AP, Baird JG et al. (1991) A comparison of long Quaternary records from the Atherton Tablelands and Western Plains volcanic provices. In: MAJ Williams et al. (eds) The Cainozoic of the Australian region: a re-evaluation of the evidence. Geological Society of Australia, pp. 288-301

Lan DZ, Yu YF, Chen CH, Xie ZT (1986) - Late Pleistocene ingressions and Holocene sea-level changes in Fuzhou basins. Mar Geol Quat Geol 6, 103-111 (in Chinese)

Ledru M-P (1993) Late Quaternary environmental and climatic changes in Central Brazil, Quat Res 39:90-98

Ledru M-P, Bertaux J, Sifeddine A, Suguio K (1998) Absence of last glacial maximum records in tropical lowland forests. Quat Res 49:233-237

Ledru M-P, Soares Braga PI, Soubies F, Fournier M, Martin L, Sugino K, Turcq B (1996) The last 50000 years in the Neotropics (Southern Brazil): evolution of vegetation and climate. Palaeogeogr Palaeoclimatol Palaeoecol 123:239-257

Leyden BW, Brenner M, Hodell DA, Curtis JH (1993) Late Pleistocene climate in the Central American lowlands. Climatic change in continental isotopic records. Geophys Monogr 78:165-178

Longmore ME (1997) Quaternary palynological records from perched lake sediments. Fraser Island, Queensland, Australia: rainforest, forest history and climatic control. Aus J Bot 45:507-526

Liu JL, Tang LY (1987) Late Pleistocene vegetational and environmental changes of Mengzhe Basin, Yunnan Province. Proc Chinese-Australia Quaternary Symp. Committee of Sino-Australian Quaternary Research (ed), Science Press, Beijing. pp 43-54

Livingstone DA (1971) A 22 000-year pollen record from the Plateau of Zambia. Limnol Oceanogr 16:349-356

Lozano-Garcia MS, Ortega-Guerrero B, Caballero-Miranda M, Urrutia-Fucuganchi J (1993) Late Pleistocene and Holocene paleoenvironments Chalco Lake, Central Mexico. Quat Res $40: 332-342$

Maitima MJ (1991) Vegetation response to climate change in Central Rift Valley, Kenya. Quat Res 35:234-245

Maley J (1987) Fragmentation de la forêt dense humide africaine et extension des biotopes montagnards au Quaternaire récent: nouvelles données polliniques et chronmologiques. Implications paléoclimatiques et biogéographiques. Palaeoecol Afr 18: 307-334

Maley J (1989) Late Quaternary climatic changes in the African rain forest: forest refugia and the major role of sea surface temperature variations. In: M Leinen, M Sarnthein (eds) Palaeoclimatology and Palaeometeorology: modern and past patterns of global atmospheric transport, Kluwer Academic Publishers, Dordrecht, NATO Advanced Science Institute Series, C: Mathematical and Physical Sciences 282, pp 585-616

Maley J (1991) The African rain forest vegetation and palaeoenvironments during Late Quaternary. Clim Change 19:79-98

Maloney BK (1980) Pollen analytical evidence for early forest clearance in North Sumatra. Nature 287:324-326

Marchant R. Taylor D, Hamilton A (1997) Late Pleistocene and Holocene History at Mubwindi Swamp, Southwest Uganda. Quat Res 47:316-328

Martin HA (1973) Palynology and historical ecology of some cave excavations in the Australian Nullabor. Aust J Bot 21:283-316

Martin PS (1964) Paleoclimatology and a tropical pollen profile. Report of the IVth International Cong Quaternary, Warsaw 1961, vol II: Palaeoclimatol Section, 319-323

Meyer ER (1973) Late-Quaternary paleoecology of the Cuatro Cienegas Basin, Coahuila, Mexico, Ecology 54:982-995

Morrison MES (1968) Vegetation and climate in the uplands of South-western Uganda during the later Pleistocene period 1. Muchoya swamp, Kigezi District. J Ecol 56:363-384

Newsome JC, Flenley JR (1988) Late Quaternary vegetational history of the Central Highlands of Sumatra. II. Palaeopalynology and Vegetational History. J Biogeogr 15:555-578

Ohngemach D, Straka H (1978) La historia de la vegetacion en la region Puebla Tlaxcala durante el cuaternario tardio. Commun Proyecto Puebla-Tlaxcala 15:189-201 
Ohngemach D, Straka H (1983) Beiträge zur Vegetations und Klimageschichte im Gebiet von Puebla-Tlaxcala. Pollen Analysen im Mexico-Projekt. Franz Steiner, Wiesbaden

Pain CF, Blong RJ (1976) Late Quaternary tephras around Mt. Hagen and Mt. Giluwe, Papua New Guinea. In: RW Johnson (ed) Volcanism in Australasia. Elsevier, Amsterdam, pp 239-251

Pereira Das Neves PC, Lorscheitter ML (1991) Upper Quaternary palaeoenvironments in the Northern Coastal Plain of Rio Grande do Sul, Brazil. Quat S Am Antarct Penin 9:39-67

Piperno DR, Bush MB, Colinvaux PA (1990) Paleoenvironments and human occupation in late-glacial Panama. Quat Res $33: 108-116$

Powell JM (1974) Preliminary report on ecological investigation of Kuk. I. The stratigraphy of the Kuk site. Ms. Prehistory Department, ANU, Canberra

Powell JM (1980) Studies of New Guinea vegetation history. Proc IV Int Palynological Conf, Lucknow (1976-77) 3:11-20

Powell JM, Kulunga A, Moge R, Pono C, Zimike F, Golson J (1975) Agricultural traditions of Mt. Hagen Area. Department of Geography, Occ Pap 12, Univ Papua New Guinea, Port Moresby

Qi W, Zheng JP (1995) Sedimentology of core ZK91-2 from Chabye Lake in Tibet and the climate and environmental evolution. J Lake Sci 7: 133-140 (in Chinese)

Qin Y, Fei AW, Jin KL, Han DX, Jin XY (1992) Pollen assemblages in Tengchong Basin, Yunnan Province and the palaeovegetation, palaeoclimate and palaeoenvironments. Mar Geol Quat Geol 12:109-118 (in Chinese)

Salgado-Labouriau ML, Cassetti V, Ferraz-Vicentini KB, Martin L, Soubiès F, Suguio K, Turcq B (1997) Late Quaternary vegetational and climatic changes in cerrado and palm swamp from Central Brazil. Palaeogeogr Palaeoclimatol Palaeoecol 128: $215-226$

Salomons JB (1986) Paleoecology of volcanic soils in the Colombia Central Cordillera (Parque Nacional Natural Los Nevados). The Quaternary of Colombia 13, Diss Bot 95:1-212

Schreve-Brinkman EJ (1978) A palynological study of the Upper quaternary sequence in the El Abra corridor and rock shelters (Colombia) Palaeogeogr Palaeoclimatol Palaeoecol 251:1-110

Scott L (1982) A late Quaternary pollen record from the Transvaal Bushveld, South Africa. Quat Res 17:339-370

Scott L (1987) Late Quaternary forest history in Venda, Southern Africa. Rev Palaeobot Palynol 53:1-10

Scott L (1989a) Late Quaternary vegetation history and climatic change in the eastern Orange Free State, South Africa. S Afr J Bot $551: 107-116$

Scott L (1989b) Climatic conditions in Southern Africa since the Last Glacial Maximum, inferred from pollen analysis Palaeogeogr Palaeoclimatol Palaeoecol 70:345-353

Scott L (1994) Palynology of Late Pleistocene hyrax middens, southwestern Cape Province, South Africa: a preliminary report: Hist Biol 9:71-81

Scott L, Thackeray JF (1987) Multivariate analysis of late Pleistocene and Holocene pollen spectra from Wonderkrater, Transvaal, South Africa. S Afr J Sci 83:93-98

Shaw PA, Coke HJ (1986) Geomorphic evidence for the late Quaternary palaeoclimates of the Middle Kalahari of northern Botswana. Catena 13:349-359

Sifeddine A, Frölich F, Fournier M, Martin L, Servant M, Soubiès F, Turcq B, Suguio K, Vollkmer-Ribeiro C (1994) La sédimentation lacustre indicateur de changements des paléoenvironments au cours des 30000 dernières années (Carajas, Amazonie, Brésil). C R Acad Sci Paris, Sér 2 318: 1645-1652

Singh G, Luly J (1991) Changes in vegetation and seasonal climate since the last full glacial at Lake Frome, South Australia. Palaeogeog Palaeoclimatol Palaeoecol 84:75-86

Song XL (1994) Pollen records and the palaeovegetation and climate. In: Palaeolimnology study of karst region in middle Yunnan Plateau, Science Press, Beijing, pp 37-46 (in Chinese)
Stevenson J (1997) Human impact from the palaeoenvironmental record of New Caledonia. Thesis Univ of New South Wales, Australia

Straka H (1996) Histoire de la végetation de Madagascar oriental dans des derniers 100 millénaires. In: WR Lourenço (ed) Biogéographie de Madagascar, ORSTOM, Paris, pp 37-47

Street-Perrott FA, Marchand DS, Roberts N, Harrison SP (1989) Global take-level variations from 18,000 to 0 years ago: a palaeoclimate analysis. US DOE/ER/60304-H1 TR046, US Department of Energy

Stuijts I (1984) Palynological study of Situ Bayongbong, West Java. Modern Quat Res S E Asia 8:17-27

Stuijts I (1993) Late Pleistocene and Holocene vegetation of West Java, Indonesia. Modern Quat Res S E Asia 12:173 p

Stute M, Talma AS (1997) Glacial temperatures and moisture transport regimes reconstructed from noble gases and O-18, Stampriet aquifer, Namibia. In: Isotope techniques in studying past and current environmental changes in the hydrosphere

Stute M, Schlosser P, Clark JF, Broecker WS (1992) Paleotemperatures in the Southwestern United States derived from noble gas measurements in groundwater. Science 256:1000-1003

Stute M, Forster M, Frischkorn H, Serejo, Clark P, Broecker WS, Bonani (1995) Cooling of tropical Brazil $\left(5^{\circ} \mathrm{C}\right)$ during the Last Glacial Maximum. Science 269:379-383

Sukumar R, Romesh R, Pant RK, Rajagopalan G (1993) A $\delta^{13} \mathrm{C}$ record of Late Quaternary climate change from tropical peats in Southern India. Nature 364:703-706

Talma AS, Vogel JC (1992) Late Quaternary paleotemperatures derived from a speleothem from Congo Caves, Cape Province, South Africa. Quat Res 37:203-213

Tang LY (1992) Vegetation and climate history at Menghai, Yunnan during the past 42,000 years. Acta Micropaleontol Sinica, 9:433-455 (in Chinese)

Tang LY, Shen CM (1996) Holocene pollen records of the Tibetan Plateau. Acta Micropalaeontol Sinica 13:407-422 (in Chinese)

Taylor DM (1990) Late quaternary pollen records from two Ugandan mires: evidence for environmental change in the Rukiga highlands of southwest Uganda. Palaeogeogr Palaeoclimatol, Palaeoecol 80:283-300

Taylor DM (1992) Pollen evidence from Muchoya swamp, Rukiga highlands (Uganda), for abrupt changes in vegetation during the last ca. 21,000 years. Bull Soc Géol Fr 163:77-92

Thompson RS, Whitlock C, Bartlein PJ, Harrison SP, Spaulding WG (1993) Climatic changes in the western United States since 18,000 yr BP. In: HE Wright Jr, JE Kutzbach, T Webb III, WF Ruddiman, FA Street-Perrott, PJ Bartelein (eds) Global climates since the Last Glacial Maximum. University of Minnesota Press, Minneapolis, pp 468-513

Torgersen T, Jones MR, Stephens AW, Searle DE and Ullman WJ (1985) Late Quaternary hydrological changes in the Gulf of Carpentaria. Nature 313:785-787

Torgersen T, Luly J, De Deckker P, Jones M, Searle DE, Chivas AL, Ullman WJ (1988) Late Quaternary environments of the Carpentaria basin, Australia. Palaeogeogr Palaeoclimatol Palaeoecol $67: 245-261$

Tsukada M (1996) Late Pleistocene vegetation and climate in Taïwan (Formosa). Proc. Nat Acad Sci 55:543-548

Tsukada M (1967) Vegetation in subtropical Formosa during the Pleistocene glaciation and the Holocene. Palaeogeogr Palaeoclimatol Palaeoecol 3:49-64

Van Devender TR (1987) Holocene vegetation and climate in the Puerto Blanco Mountains, southwestern Arizona. Quat Res $27: 51-72$

Van Devender TR, Spaulding WG (1979) Development of vegetation and climate in the southwestern United States. Science 204: 701-710

Van Devender TR, Thompson RS, Betancourt JL (1987) Vegetation history of the deserts of southwestern North America; The nature and timing of the Late Wisconsin-Holocene transition. In: WF Ruddiman and HE Wright, Jr (eds) North America and adjacent 
oceans during the last deglaciation, the geology of North America Vol K-3. The Geological Society of America, Boulder, Colorado, pp 323-352

Van der Hammen T (1963) A palynological study on the Quaternary of British Guiana. Leidse Geol Meded 29:125-160

Van der Hammen T (1974) The Pleistocene changes of vegetation and climate in tropical South America J Biogeogr 1:3-26

Van der Hammen T, Absy ML (1994) Amazonia during the last glacial. Palaeogeog, Palaeoclimatol, Palaeoecol 109:247-261

Van der Hammen T, Gonzalez E (1960) Upper Pleistocene and Holocene climate and vegetation of the Sabana de Bogota. Leidse Geol Meded 25:261-315

Van der Hammen T, Cleef AM, Noldus GW (1995) A palynological record of the Rosarita pedo-tephro stratigraphical sequence (Central Cordillera, Colombia): vegetational history of the last 35,000 years. In: T Van der Hammen, GA Dos Santos (eds) Studies on tropical Andean ecosystems/Estudios de Ecosistemas Tropandinos 4, Berlin - Stuttgart, Cramer (Borntraeger), pp 431-439

Van der Hammen T, Duivenvoorden JF, Lips JM, Urrego LE, Espejo N (1992) Late Quaternary of the middle Caquetà River area (Colombian Amazonia). J Quat Sci 7:45-55

Van der Kaars WA, Dam MAC (1994) Palynology of Bandung basin sediments. In: MAC Dam (ed), The Late Quaternary evolution of the Bandung Basin, West Java, Indonesia, CIP-Gegevens Kon Bibl, Den Haag, pp 173-186

Van Geel B, Van der Hammen T (1973) Upper Quaternary vegetational and climatic sequence of the Fuquene area (eastern Cordillera, Colombia). Palaeogeog, Palaeoclimatol, Palaeoecol 14:9-92

Vasanthy G (1988) Pollen analysis of Late Quaternary sediments: evolution of upland savanna in Sandynallah (Nilgiris, South India). Rev Palaeobot, Palynol 55:175-192

Vincens A (1989) Les forêts claires zambéziennes du bassin SudTanganyika. Evolution entre 25000 et 6000 ans B.P. C R Acad Sci Paris 308 II : 809-814

Vincens A (1991a) Late quaternary vegetation history of the SouthTanganyika basin. Climatic implications in South Central Africa. Palaeogeogr Palaeoclimatol Palaeoecol 86:207-226

Vincens A (1991b) Végétation et climat dans le bassin Sud-Tanganyika entre 25000 et 9000 B.P.: nouvelles données palynologiques Palaeoecol Afr 22:253-263

Vincens A (1993) Nouvelle séquence pollinique du lac Tanganyika: 30000 ans d'histoire botanique et climatique du Bassin Nord. Rev. Palaeobot Palynol 78:381-394

Vincens A, Chalie F, Bonnefille R, Guiot J, Tiercelin JJ (1993) Pollen-derived rainfall and temperature estimates from Lake Tanganyika and their implications for Late Pleistocene water levels. Quat Res 40:343-350

Vishnu-Mittre, Sharma C (1984) Vegetation and Climate during the Last Glaciation in the Kathmandu Valley, Nepal, Pollen Spores $26: 69-94$
Walker D, Flenley JR (1979) Late Quaternary vegetational history of the Enga District of Upland Papua New Guinea. Philos Trans R S B 286:265-344

Watts WA, Bradbury PJ (1982) Palaeoecological studies at lake Patzcuaro on the west-central Mexican Plateau and at Chalco in the basin of Mexico. Quat Res 17:56-70

Watts WA, Hansen BCS (1988) Environments of Florida in the Late Wisconsin and Holocene. In: B Burdy (ed) Wet site archeology. Telford Press, NJ Caldwell, pp 307-323

Watts WA, Stuiver M (1980) Late Wisconsin climate of northern Florida and the origin of the species-rich deciduous forest. Science $210: 325-327$

Watts WA, Hansen BC, Grimm EC (1992) Camel lake: A 40,000-yr record of vegetational and forest history from North-West Florida. Ecology 73 : 1056-1066

Webb III T, Bartlein PJ, Harrison SP, Anderson KH (1993) Vegetation, lake levels, and climate in Eastern North America for the past 18,000 years. In: HE Wright Jr, E Kutzbach, T Webb III Ruddiman, FA Street-Perrott and PJ Bartlein (eds) Global climates since the Last Glacial Maximum. University of Minnesota Press, Minneapolis, pp 413-467

Wells RV (1966) Late Pleistocene vegetation and degree of pluvial climatic change in the Chihuahua Desert. Science 153:970-975

White JP, Crook KAW, Buxton BP (1970) Kosipe: a late Pleistocene site in the Papuan highlands. Proc Prehist Soc 36:152-170

Wijmstra TA (1969) Palynology of the Alliance Well. Geol Mijnb $48: 125-133$

Wilkins DE, Currey DR (1997) Timing and extent of Late Quaternary paleolakes in the Trans-Pecos Closed Basin, west Texas and south-central New Mexico. Quat Res 47:306-317

Wirrman D, Mourgiart P (1995) Late Quaternary spatio-temporal limnological variations in the Altiplano of Bolivia and Peru. Quat Res 43:344-354

Wu SG, Han HY, Yu JB (1995) Late Quaternary sediments and palaeoenvironments in Behenyin Basin, Guizhou Province. Geogr Res 14(2): 49-55 (in Chinese)

Wu YS, Xiao JY (1996) Pollen records from Zabuyehu Lake in Tibet during the last 30,000 years. Mar Geol Quat Geol 16:115-121 (in Chinese)

Xu X, Zhang SW, Zhou S (1987) Preliminary study of vegetation, climate and environment in Wuhu-Jiangying regions since 30,000 years ago. J Nanjing Univ (Nat Sci Ser) 23:556-577 (in Chinese)

Yamanaka M, Ishikawa S (1991) A preliminary pollen analytical study on the Quaternary deposits from the Kathmandu Valley, central Nepal, Ecol Rev Sendai 22:71-76

Ybert JP (1991) Los paisajes lacustres antiguos segœn el analisis palinológico In: C Dejoux, A Iltis (eds) El lago Titicaca, Síntesis del conocimiento limnológico actual. ORSTOM-HIBOL, La Paz, Bolivia, 69-79

Zhu HH (1989) Environments and sedimentology of the fault lake of Yunnan. Science Press, Beijing, 513 p (in Chinese) 